\title{
32. DIAGENETIC HISTORY OF CRETACEOUS RADIOLARIANS, NORTH ATLANTIC OCEAN (ODP LEG 103 AND DSDP HOLES 398D AND 603B) ${ }^{1}$
}

\author{
Jürgen Thurow, Institut für Paläontologie der Universität Tübingen, Federal Republic of Germany
}

\begin{abstract}
Radiolarian-rich sediments from several sites in the North Atlantic (DSDP Holes 398D and 603B and ODP Holes $638 \mathrm{~B}, 638 \mathrm{C}, 640 \mathrm{~A}, 641 \mathrm{~A}$, and $641 \mathrm{C}$ ) were studied in order to understand the diagenetic history of radiolarian skeletons as they transformed from biogenic opal (opal-A) into silica (opal-CT and quartz) and zeolites. Replacement of skeletons by carbonates and sulfides in response to the lithology of the host sediment was also studied.

The diagenetic history of radiolarians was determined from thin-section, grain mount, EDAX, and XRD data. The most important types of radiolarian alteration are (1) replacement of opal-A by opal-CT, (2) dissolution of skeletons, (3) replacement of skeletons by zeolites, especially by clinoptilolite, (4) replacement of zeolites by pyrite, (5) replacement of biogenic opal-A by pyrite, (6) formation of internal casts and dissolution of skeletons, and (7) replacement of skeletons by calcite.

Correlations exist between the lithology of the host rock and the diagenetic replacement mineral of the radiolarians. The most obvious link is between high carbonate content (pelagic limestone) and the occurrence of calcite-replaced radiolarian tests. Pelagic claystone or marly claystone contains silica-replaced (opal-CT and clinoptilolite) radiolarian faunas. Enrichment of organic matter, especially of terrestrial origin, leads to radiolarian replacement and overgrowth by pyrite. A review of the possible patterns of skeletal replacement as well as of the possible lithology/diagenesis relationships is given, although many questions related to the replacement of skeletons by pyrite and zeolite remain.
\end{abstract}

\section{INTRODUCTION}

In general, the preservation of Cretaceous radiolarians in Atlantic Ocean sediments is poor. Under the SEM, even apparently well-preserved faunas show advanced stages of diagenetic alteration. During biostratigraphic studies of radiolarians from several North Atlantic sites-Deep Sea Drilling Project (DSDP) Hole 398D and Ocean Drilling Program (ODP) Holes 638B, $638 \mathrm{C}, 640 \mathrm{~A}, 641 \mathrm{~A}$, and $641 \mathrm{C}$ in the eastern North Atlantic (Fig. 1) and DSDP Hole 603B in the western North Atlantic (Fig. 2) - many varieties of alteration and replacement mineralogy were observed, from which a history of several diagenetic steps was identified.

Many studies related to silica diagenesis have been made, based mainly on DSDP data, with the primary objective of explaining the origin of marine porcellanites/cherts (compilation in Wise and Weaver, 1974; Pisciotto, 1981). In particular, clinoptilolites are discussed by Kastner and Stonecipher (1978) and Stonecipher $(1976,1978)$. Regional studies from the Pacific and adjacent areas are numerous: Bramlette (1946), Heath and Moberly (1971), Heath (1973), Lancelot (1973), Kastner and Keene (1975), Keene (1975), Hein et al. (1981), Pisciotto and Garrison (1981), Ijima et al. (1983), and Murata and Larson (1975). Studies of the North Atlantic include von Rad and Rösch (1974), von Rad et al. (1977), Mélières (1979), Riech and von Rad (1979a, 1979b), Otsuoka (1985), and Thein and von Rad (1987). Most of the authors relate porcellanite/chert occurrences to abundant deposition of biogenic opal-A, for which a favorable depositional environment exists beneath upwelling areas with high plankton productivity. Other authors, however, describe direct crystallization of quartz from pore solutions and the occurrence of porcellanites directly associated with volcanogenic material.

Because data about the diagenetic alteration of radiolarians are widespread in the literature, this study focuses only on radi-

\footnotetext{
${ }^{1}$ Boillot, G., Winterer, E. L., et al., 1988. Proc. ODP, Sci. Results, 103: College Station, TX (Ocean Drilling Program).
}

olarian replacement processes. The Cretaceous formations at the studied North Atlantic sites can be correlated; therefore, we refer to the North Atlantic formation names established by Jansa et al. (1979) (see also Table 1):

1. Reddish or brown carbonate-free clay (Turonian-Tertiary; Plantagenet Formation).

2. Black shale (Cenomanian/Turonian Boundary EventCTBE).

3. Gray green marl/black shale couplets (Barremian-Cenomanian; Hatteras Formation).

4. Pale limestone or marl, often intensely bioturbated (Barremian and older; Blake-Bahama Formation). At Holes 603B, $638 \mathrm{~B}$, and $638 \mathrm{C}$, these sediments are interbedded with a clastic turbidite/organic-carbon-enriched calcareous claystone sequence of Valanginian-Hauterivian age. More than $250 \mathrm{~m}$ of turbidites were recorded in Hole 603B (Sarti and von Rad, 1987).

Locally recorded minor lithologies, including bioclastic turbidites (Aptian-Albian) and pelagic marl (Berriasian), are not given formal formation names.

\section{METHODS}

The radiolarian content in the studied samples was generally too low for detection of their mineralogy by the analysis of bulk samples by Xray diffraction (XRD). Even after dissolution of the carbonate with $\mathrm{HCl}$, the radiolarian mineralogy could not be unambiguously detected because of the high clay content and percentage of detrital components. Thus, the samples were treated with $\mathrm{HCl}(5 \%)$ followed with $\mathrm{H}_{2} \mathrm{O}_{2}(35 \%$ + chalk as buffer for pyrite oxidation) and finally washed through a 40$\mu \mathrm{m}$ sieve; samples with calcite-replaced faunas noted in thin sections were treated with detergent (REWOQUAT), which allowed for faunal extraction without destruction. Radiolarians or their alteration products were hand-picked and mounted on SEM stubs. A sample of the host sediment was also mounted for study with the SEM and EDAX. Some residues were powdered and analyzed by XRD.

We used the terminology of Jones and Segnit (1971) to describe the transformation from biogenic opal-A to opal-CT, and finally, to quartz. Zeolites are described chiefly as clinoptilolite, after testing of two zeo- 
A

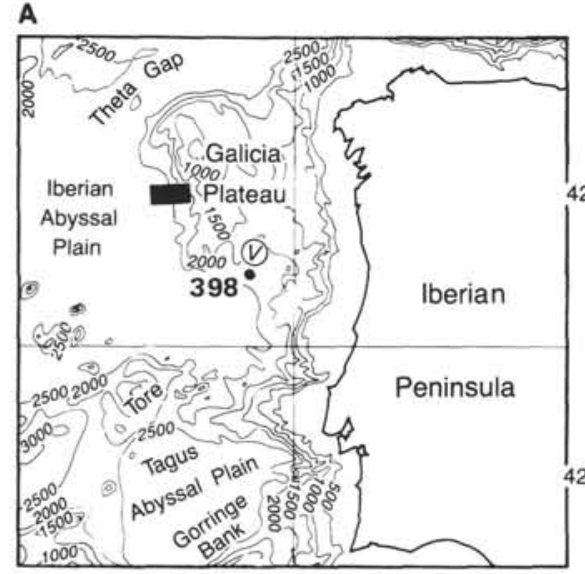

B

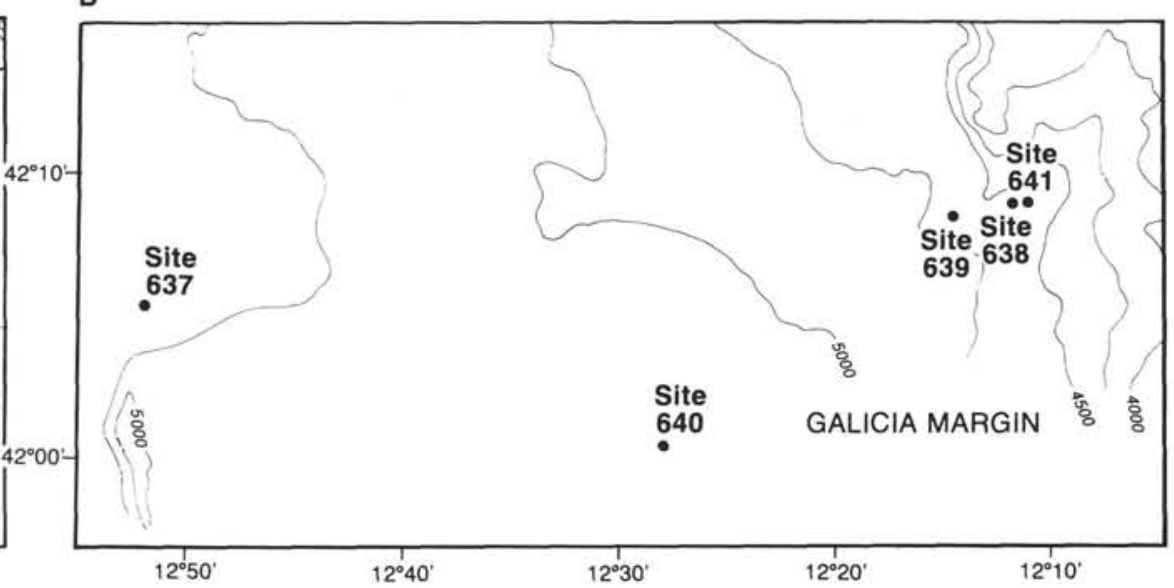

Figure 1. Location of DSDP Site 398 and ODP Sites 638, 640, and 641 in the eastern North Atlantic.

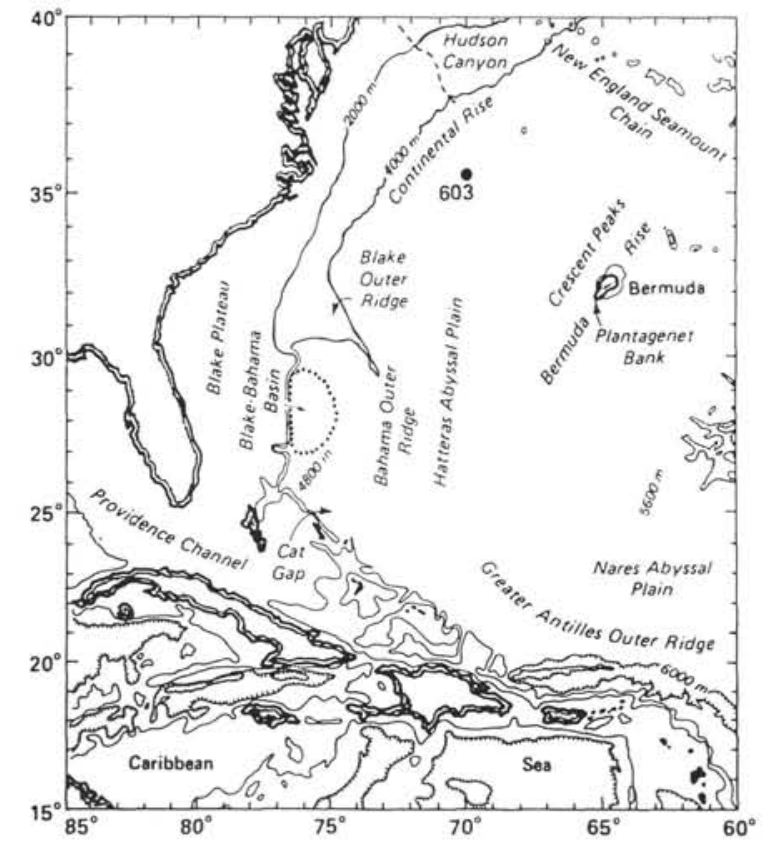

Figure 2. Location of DSDP Site 603 in the western North Atlantic.

lite-rich samples with the heating method (Fig. 3) (Mumpton, 1960) revealed the characteristic XRD pattern for clinoptilolite.

Radiolarian abundance and diagenetic alteration, as well as abundances of quartz, zeolite, and pyrite and the ratio of total organic carbon to carbonate content, are plotted in Figures 4-6. The data for these plots are from thin-section, smear slide, and geochemistry data from the Initial Reports chapters for Sites 398, 603, 638, 640, and 641 (Shipboard Scientific Party, 1979, 1987a, 1987b, 1987c, 1987d), Sigal (1979), and studies by the author (compare with Thurow et al., this volume, Tables 1 and 2 and Figures 3-5). Lithologies with a high content of terrigenous material are not considered in Figures 4-6.

Percentages of clay minerals at Site 398 and the Leg 103 sites are from the "Site 398" chapter summary chart (Shipboard Scientific Party, 1979) and from Meyer and Davies (this volume) and Thurow et al. (this volume), respectively. Information about the abundance and preservation of radiolarians in the studied samples is compiled in Appendix B. The diagenetic alteration types of radiolarians described from all sites on the basis of strewn slides and washed residues are also listed in Appendix B.

\section{HOST SEDIMENT LITHOLOGY, RADIOLARIAN OCCURRENCES, AND SKELETAL REPLACEMENT MINERALOGY}

Diagenetically altered radiolarians have been observed from various lithologies within the Cretaceous North Atlantic formations of Jansa et al. (1979).

The Plantagenet Formation has locally developed distinctive lithologies. The Campanian section contains an olive-gray/olive-brown zeolite- and radiolarian-rich facies from which washed residues (up to $25 \%$ of the bulk volume) show a white sand that consists entirely of radiolarians recrystallized to clinoptilolite (e.g., Hole 603B; Pl. 5, Fig. 1; see also Thurow, this volume). The base of the Plantagenet Formation, just above the CTBE, consists in some places of a multicolored zeolitic clay (e.g., Site 105). At Hole $641 \mathrm{~A}$, this clay (only gray-green in color) is devoid of radiolarians but strongly enriched in clinoptilolite. Radiolarians in deep-sea sediments deposited during the CTBE show different types and degrees of preservation. At Hole 398D (Sections 2-5 of Core 56) CTBE lithologies include black shale, gray-green claystone, and reddish claystone, all of which contain common radiolarians replaced by opal-CT. Radiolarians in the reddish and black facies are strongly corroded and zeolitized, whereas preservation is moderate in the gray-green facies. The reddish claystones (e.g., Sample 398D-56-2, 2-6 cm) intercalated with the younger CTBE deposits contain abundant, poorly preserved radiolarians (Thurow, this volume). At Hole 603B (Sections 603B-33, CC, and 603B-34-1 through 603B-34-3), black shales contain only rare occurrences of strongly corroded and opal-CT-replaced skeletons with smooth surfaces. The lower Turonian claystone above the black shale contains abundant opalCT- and zeolite-replaced radiolarians with the typical CTBE faunal composition (Thurow, this volume). At Hole 641A (Samples 103-641A-6X-7, $17 \mathrm{~cm}$, to 103-641A-6X, CC [27 cm]), no radiolarians were found in the black shale layer and in the graygreen sections above and below it, but the samples contain large amounts of zeolite.

Radiolarians are common throughout the Hatteras Formation. Preservation is variable but generally poor. At Hole 398D (Cores 398D-57 through 398D-130; middle Barremian to Cenomanian), radiolarians are replaced by opal-CT (quartz?) and often strongly recrystallized. Replacement of radiolarian skeletons by pyrite (as reported by Sigal, 1979) was not observed. Nevertheless, pyrite is common in the sediment throughout the formation. At Hole 603B, radiolarians are rare and concentrated in 
Table 1. Summary chart of host sediment lithology, radiolarian preservation, and paleoceanography. Compiled from Arthur and Natland (1979), Chamley (1979), Jansa et al. (1979), Shipboard Scientific Party (1979), de Graciansky et al. (1982), Thurow et al. (1982), Chamley and Debrabant (1984), Chamley and Deconinck (1985), Brumsack and Thurow (1986), Stein et al. (1986), Thurow and Kuhnt (1986), von Rad and Sarti (1986), Herbin et al. (1987), Kuhnt et al. (1987), Ogg et al. (1987), Sarti and von Rad (1987), Schlanger et al. (1987), and Shipboard Scientific Party (1987a, 1987b, 1987c, 1987d). Ages are from Sigal (1979), Moullade et al. (this volume), and Thurow (this volume).

\begin{tabular}{|c|c|c|c|c|}
\hline & $\begin{array}{l}\text { Plantagenet Formation } \\
\text { without Crescent Peaks member } \\
\text { (only the Cretaceous was studied) }\end{array}$ & $\begin{array}{l}\text { Cenomanian/Turonian } \\
\text { Boundary Event }\end{array}$ & Hatteras Formation & $\begin{array}{l}\text { Blake-Bahama Formation } \\
\text { (only the Cretaceous was studied) }\end{array}$ \\
\hline Type section & Site 386 & Not defined & Site 105 & Hole 391C \\
\hline Distribution & Widespread in North Atlantic/Western Tethys & Widespread in North Atlantic/Western Tethys & Widespread in North Atlantic and Western Tethys & $\begin{array}{l}\text { Widespread in North Atlantic, locally in West- } \\
\text { ern Tethys }\end{array}$ \\
\hline Holes studied & 398D, 603B, and 641A & 398D, 603B, and 641A & 398D, 603B, and 64IC & 398D, 638E, 638C, 640A, and 641C \\
\hline & Turonian-Maestrichtian & $\begin{array}{l}\text { Late Cenomanian-early Turonian } \\
\sim 3(398 D) \cdot-6(603 B): \sim 0.3(641 \mathrm{~A})\end{array}$ & Aptian/Barremian-Cenomanian & Valanginian-Barremian \\
\hline Major lithologies & Carbonate-free varigated clay & $\begin{array}{l}\text { Zeolitic black shale with strong trace metal } \\
\text { enrichment }\end{array}$ & $\begin{array}{l}\text { Dark green-gray to black carbonaceous claystone } \\
\text { and shale }\end{array}$ & $\begin{array}{l}\text { Light-colored nannofossil limestone, marl, and } \\
\text { in places, chert }\end{array}$ \\
\hline $\begin{array}{l}\text { Local lithologies (different from type } \\
\text { section) }\end{array}$ & $\begin{array}{l}\text { Red to brown marly chalk (Hole 398D: Campanian/ } \\
\text { Meastrichtian) } \\
\text { Reddish siliceous claystone (Hole 398D: lower Turo- } \\
\text { nian) } \\
\text { Reddish brown and green-gray claystone (Hole 603B: } \\
\text { lower Turonian, lower Campanian) }\end{array}$ & $\begin{array}{l}\text { Hole 398D: interstratification of gray-green } \\
\text { claystone and black shale }\end{array}$ & $\begin{array}{l}\text { Calciturbidites with shallow-water debris } \\
\text { Hole 398D: upper Aptian (break-up unconform- } \\
\text { ity) } \\
\text { Hole 341C: upper Aptian (break-up unconform- } \\
\text { ity) }\end{array}$ & $\begin{array}{l}\text { Sandstone and organic-matter-rich turbidites } \\
\text { Hole 603B: } 300 \text { (upper Valanginian-Barremian) } \\
\text { Site 688: 200 (valanginian-Hauterivian) } \\
\text { Reworked Weald-type sediment }\end{array}$ \\
\hline $\begin{array}{l}\text { Clay minerals } \\
\text { (Sites } 398,638,640 \text {, and 641) }\end{array}$ & $\begin{array}{l}\text { Smectite: } 50 \% \text { (Hole 641A): 40\% (Hole 398D) } \\
\text { Illite: } 25 \% \text { (Holes } 398 \mathrm{D} \text { and 641A) } \\
\text { Kaolinite: } 13 \% \text { (Hole 641A) } \\
\text { Palygorskite: } 13 \% \text { (Holes 398D and 641A) }\end{array}$ & $\begin{array}{l}\text { Smectite: } 80 \% \\
\text { Illite: } 20 \% \\
\text { Palygorskite: } 20 \% \\
\text { (Hole 398D: only green-gray claystones) }\end{array}$ & $\begin{array}{l}\text { Smectite: } 50 \% \\
\text { llite: } 40 \% \% \\
\text { Palygorskite: up to } 40 \% \text { in the upper part of the } \\
\text { formation }\end{array}$ & $\begin{array}{l}\text { Smectite: } 40 \% \\
\text { IIlite: } 30 \% \\
\text { Kaolinite + chlorite: } 5 \%-50 \%\end{array}$ \\
\hline $\begin{array}{l}\text { Total organic carbon content and } \\
\text { calcium carbonate content }\end{array}$ & See Figs. 5-7 & See Figs. 5-7 & See Figs. 5-7 & See Figs. 5-7 \\
\hline $\begin{array}{l}\text { Onshore equivalents (chiefly Western } \\
\text { Mediterranean area and Alpine } \\
\text { Fold Belt) }\end{array}$ & $\begin{array}{l}\text { Above CCD: "Scaglia Rossa" } \\
\text { "Couches Rouges" Southern Europe } \\
\text { Below CCD: "Scisti Policromi" } \\
\text { "Argillite Series II" Southern Europe }\end{array}$ & $\begin{array}{l}\text { "Livello Bonarelli" Southern Europe } \\
\text { "Black Band" Northern Europe }\end{array}$ & $\begin{array}{l}\text { "Scisti a Fucoidi" } \\
\text { "Scisti Neri" "outhern Europe } \\
\text { "Flysch Noir" } \\
\text { "Argillite Series I" Northern Africa }\end{array}$ & "Majolica" Southern Europe \\
\hline $\begin{array}{l}\text { Radiolarians } \\
\text { Radiolaria-bearing intervals and } \\
\text { abundance }\end{array}$ & See Figs. 5-7 & See Figs. 5-7 & See Figs. 5-7 & See Figs. 5-7 \\
\hline Skeletal replacement mineralogy & $\begin{array}{l}\text { Dominant: clinoptilolite } \\
\text { Minor: opal-CT }\end{array}$ & $\begin{array}{l}\text { Dominant: clinoptilolite } \\
\text { Minor: opal-CT }\end{array}$ & $\begin{array}{l}\text { Dominant: opal-CT } \\
\text { Minor: pyrite; clinoptilolite (clinoptilolite casts } \\
\quad \text { are common) }\end{array}$ & $\begin{array}{l}\text { Dominant: calcite (in limestone; when biotur- } \\
\text { bated, pyrite replacement occurs) } \\
\text { Dominant: pyrite (in organic-matter-rich clay- } \\
\text { stone) } \\
\text { Minor: opal-CT/quartz (in limestone) } \\
\text { Internal casts of clinoptilolite occur in the upper } \\
\text { part of the formation }\end{array}$ \\
\hline \multicolumn{5}{|l|}{ Paleoceanography ${ }^{\mathrm{a}}$} \\
\hline $\begin{array}{l}\text { Paleoceanographic biosiliceous } \\
\text { events }\end{array}$ & $\begin{array}{l}\text { Oxic } \\
\text { Early Campanian (end of OAE 3) }\end{array}$ & $\begin{array}{l}\text { Anoxic } \\
\text { Cenomanian/Turonian (OAE 2) } \\
\text { Cenomanian/Turonian Boundary Event } \\
\text { (CTBE) }\end{array}$ & $\begin{array}{l}\text { Anoxic/oxygen-depleted } \\
\text { Barremian/Aptian (onset of OAE 1) } \\
\text { Selli Event }\end{array}$ & Oxic/oxygen-depleted \\
\hline General paleoceanography & & $\begin{array}{l}\text { Rearrangement of oceanic circulation pat- } \\
\text { tern; strong differences in faunal assem- } \\
\text { blages before and after the event }\end{array}$ & $\begin{array}{l}\text { End of nannoplankton-rich facies } \\
\text { Radiation of planktonic foraminifers }\end{array}$ & \\
\hline
\end{tabular}

$\mathrm{OAE}=$ Oceanic Anoxic Event 


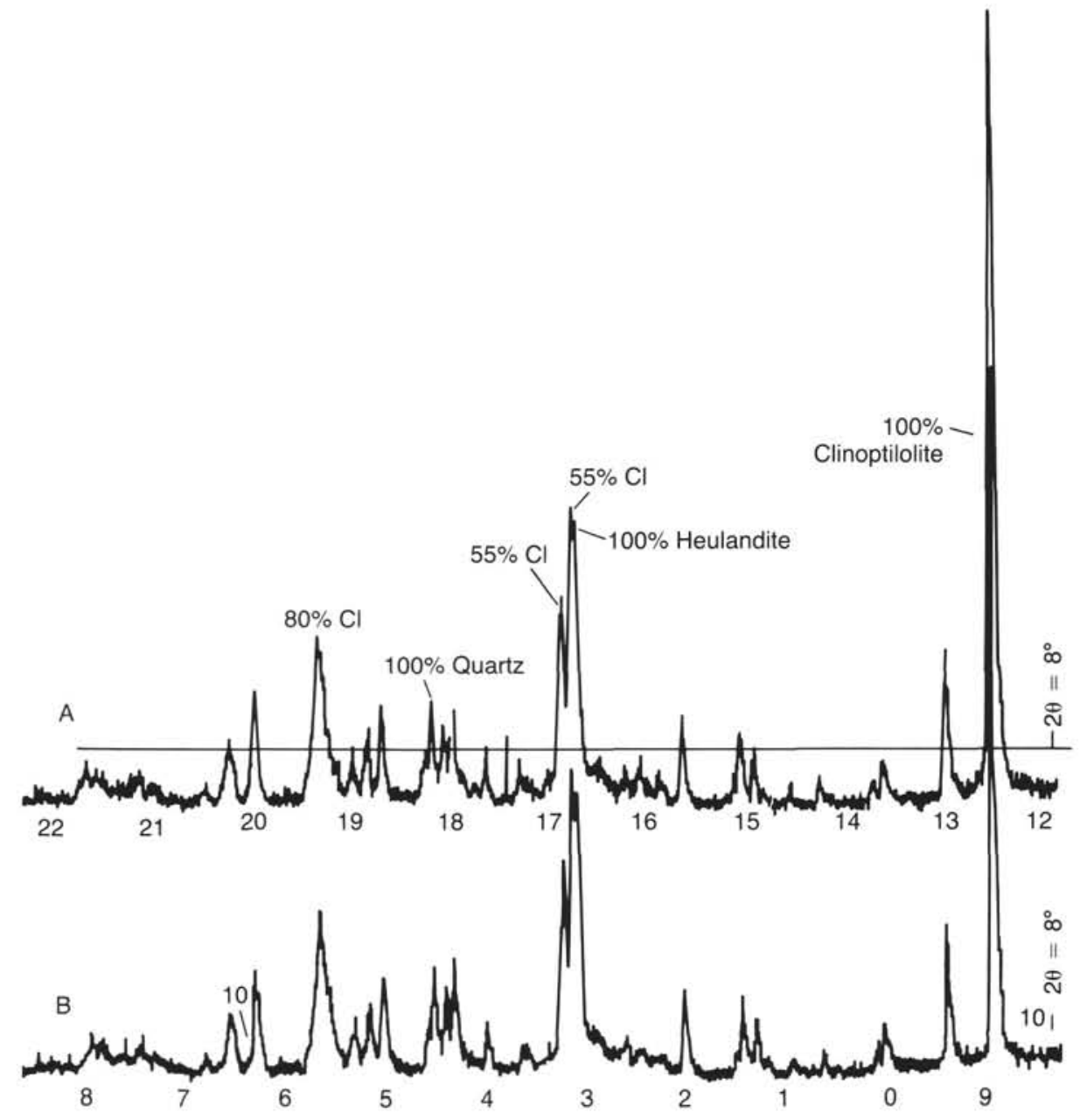

Figure 3. Powder diffraction of zeolites from Sample 603B-26-2, 90-93 cm. The lower plot (B) shows a typical heulandite/clinoptilolite pattern; the upper plot (A) shows the zeolite pattern after heating for $15 \mathrm{hr}$ at $450^{\circ} \mathrm{C}$. The unchanged pattern of the zeolite peaks proves that the zeolite is a clinoptilolite.

a few layers in the upper part of the Hatteras Formation ("Biostratigraphic Summary," "Site 603" chapter; Shipboard Scientific Party, 1987a). These radiolarians are replaced by pyrite. At Hole $641 \mathrm{C}$, radiolarians are common to abundant and are, with few exceptions, replaced by opal-CT in the interval between Samples 103-641C-1R-1, 36-38 cm, and 103-641C-10R-2, 45-48 $\mathrm{cm}$. Zeolite casts or dense microcrystalline casts of zeolite and clay are common. Between Sample 103-641C-10R-4, 26-30 cm, and Section 103-641C-16R, CC, radiolarians are replaced by silica (opal-CT transitional to quartz, as suspected from thin-section studies) or rarely replaced by pyrite. The location of the boundary with the underlying Blake-Bahama Formation, which occurs within this interval, is not precisely known, but it may coincide with the boundary between the lithologic Units $\mathrm{V}$ and VI (103-641C-11R-3, $26 \mathrm{~cm}$ ), which itself coincides with a strong increase of pyrite-replaced radiolarians.

Variably preserved radiolarians are common throughout the Blake-Bahama Formation in Holes 603B, 638B, and 641C. By far, the most common diagenetic process observed in these radiolarians is dissolution of the primary skeleton and precipitation of coarse calcite casts (Pl. 8, Fig. 5). In strongly bioturbated areas, the radiolarians were replaced by pyrite and filled with coarse calcite. Radiolarians in the detrital calcareous claystone are always replaced by pyrite (Pl. 6, Fig. 2), in addition to common strong pyrite recrystallization with pyrite overgrowth. At Hole 398D, only the uppermost part of the Blake-Bahama Formation was drilled; the radiolarians are again represented by calcite casts, but some poorly preserved silica-replaced skeletons remain. No samples from the Blake-Bahama Formation in Hole 603B were studied; data about radiolarian diagenesis in this section are presented by Thein and von Rad (1987) and Ogg et al. (1987). Figures 4-6 and Table 1 provide a compilation of sedimentological, diagenetic, and paleoceanographic information related to sediments from all of these formations.

\section{DIAGENETIC REPLACEMENT PROCESSES}

We observed the following replacement/alteration processes in radiolarians:

1. Replacement of opal-A by opal-CT, with rare recrystallization to quartz (type A)

2. Surface dissolution (corrosion) of skeletons (type B)

3. Replacement of skeletons by zeolites, especially by clinoptilolite (type C)

4. Replacement of zeolites by pyrite (type D)

5. Replacement of opal-A by pyrite (type E) 


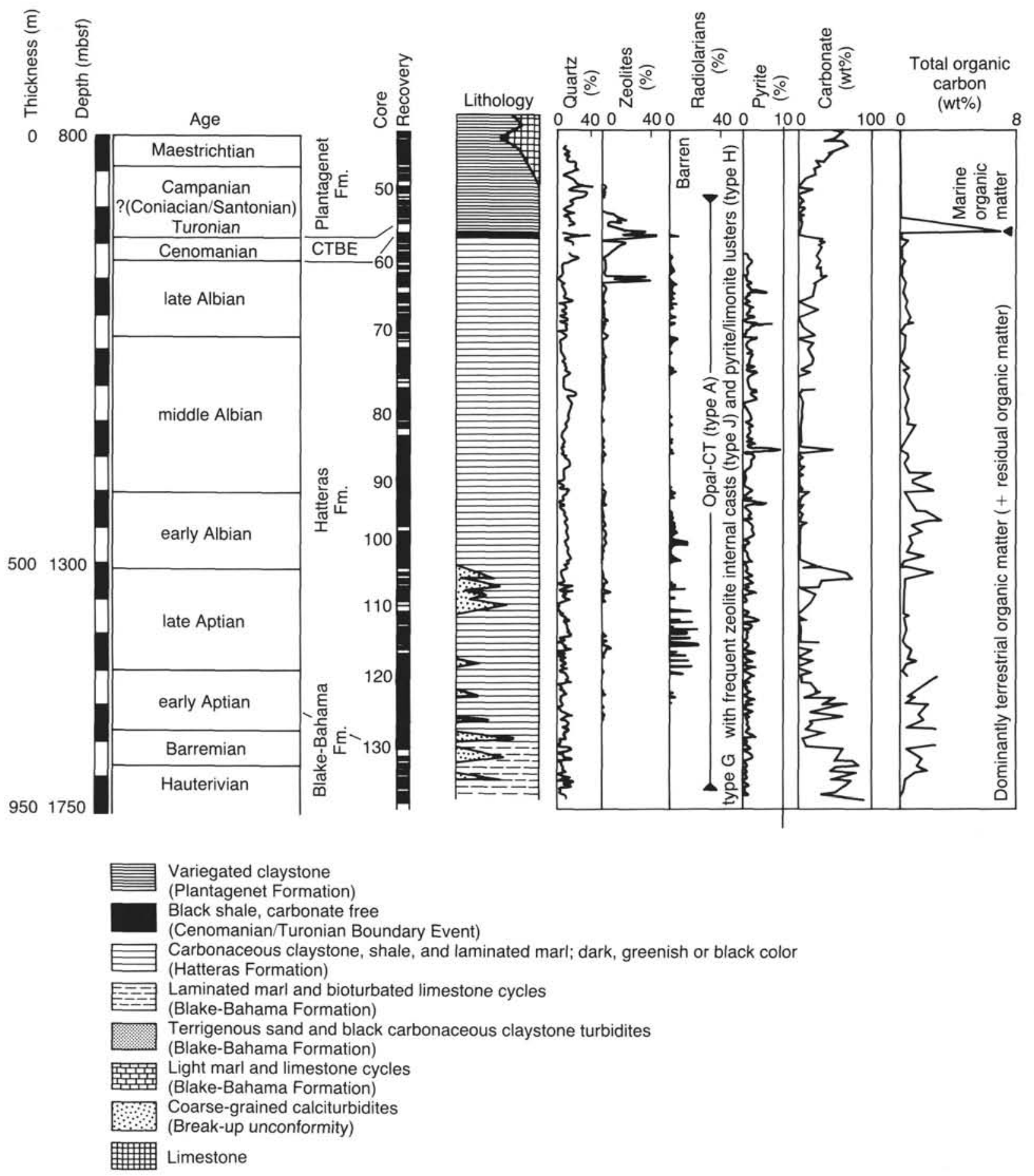

Figure 4. Summary of radiolarian abundance, preservation, alteration, and mineralization and accompanying minerals in relation to the host lithology of Hole 398D.

6. Formation of pyrite internal casts and dissolution of primary skeletons (type F)

7. Replacement of skeletons by calcite (type G).

The following processes are less important (Figs. 4-7):

8. Pyrite/limonite lusters on skeletons (type $\mathrm{H}$ ) J)

9. Zeolite internal casts (not always easily detectable) (type
10. Monospecific replacement by a certain mineral (e.g., opal$\mathrm{CT}$, whereas all other forms are replaced by pyrite) (type K).

\section{Opal-A Replacement by Opal-CT or Quartz (Type A)}

Skeletons are replaced with silica by transformation of the biogenic opal-A into opal-CT (Fig. 7A; Jones and Segnit, 1971). Final transformation to microcrystalline quartz was rarely observed in thin sections. 


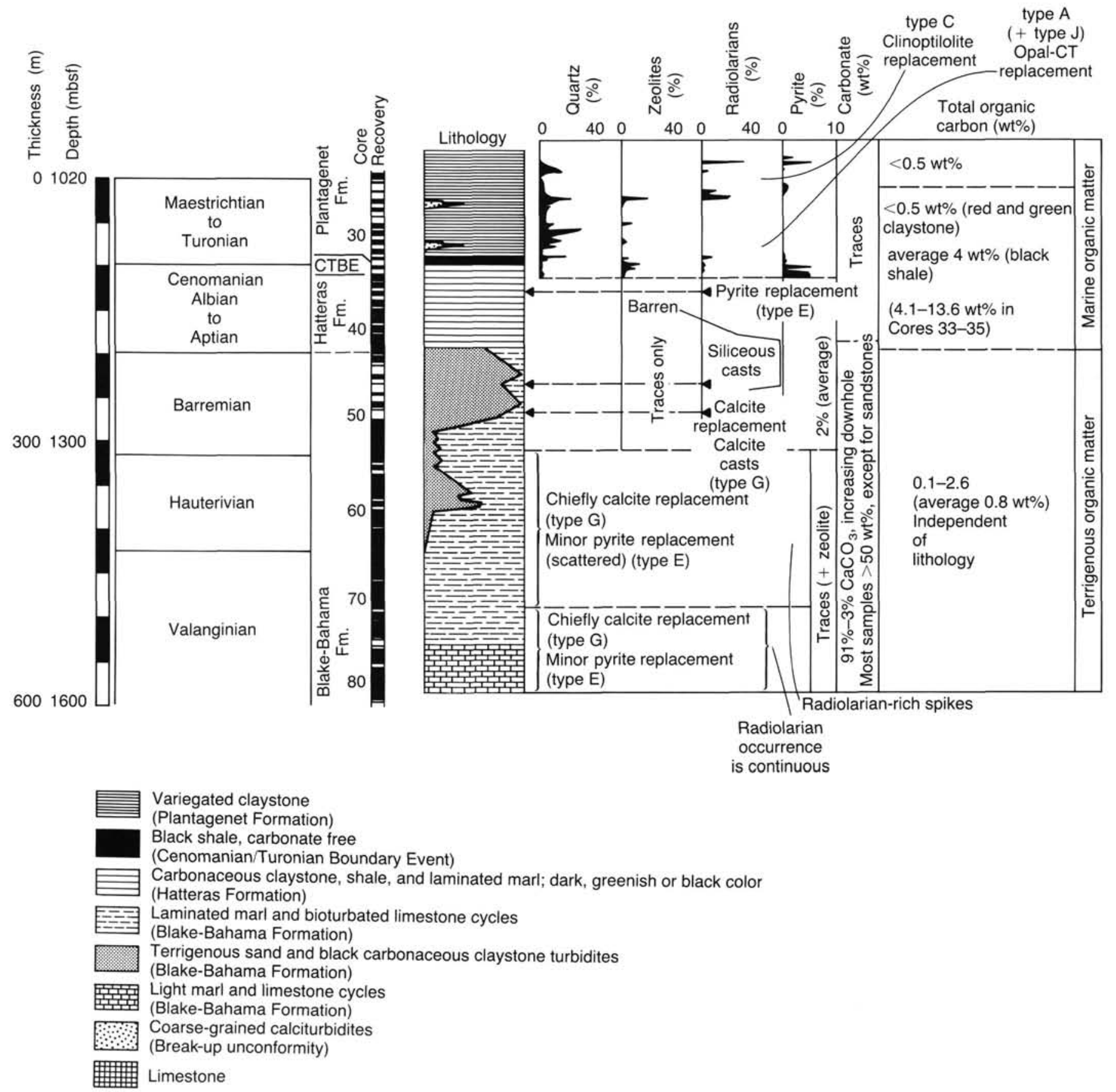

Figure 5. Summary of radiolarian abundance, preservation, alteration, and mineralization and accompanying minerals in relation to the host lithology of Hole 603B.

There was no evidence for the preservation of any opal-A. Several authors (e.g, Riech and von Rad, 1979a) have found the preservation of biogenic opal-A to be a function of age, burial depth (temperature), and the host rock facies. According to Riech and von Rad (1979a) and Thein and von Rad (1987), opal-A in the Atlantic Ocean is stable only in sediments not older than Late Cretaceous, and then only at shallow depths of burial $(0-400 \mathrm{~m})$. In this paper, the youngest samples are early Campanian in age, and as they were most likely buried beneath a thick Tertiary sediment cover, we assume that no radiolarian skeletons of primary opal-A (biogenic opal) occur in the Cretaceous samples studied.
All tests are recrystallized to some extent. The primary biogenic opal-A is either replaced by opal-CT (Fig. 7B) or, in a more advanced diagenetic stage, recrystallized to quartz, which in turn can be dissolved. Thin-section studies of samples from the lower part of the Hatteras Formation and from the BlakeBahama Formation reveal distinct nuclei of quartz crystals in the outer parts of the opal-CT-replaced radiolarians.

Some $\mathrm{HCl}$-etched residues of radiolarian samples indicate moderately to well-preserved radiolarian assemblages (PI. 1, Fig. 1) that, however, have all been altered to a certain degree. In the more calcareous environments of the Lower Cretaceous at Holes $638 \mathrm{~B}, 638 \mathrm{C}$, and $640 \mathrm{~A}$, the radiolarians are commonly replaced 


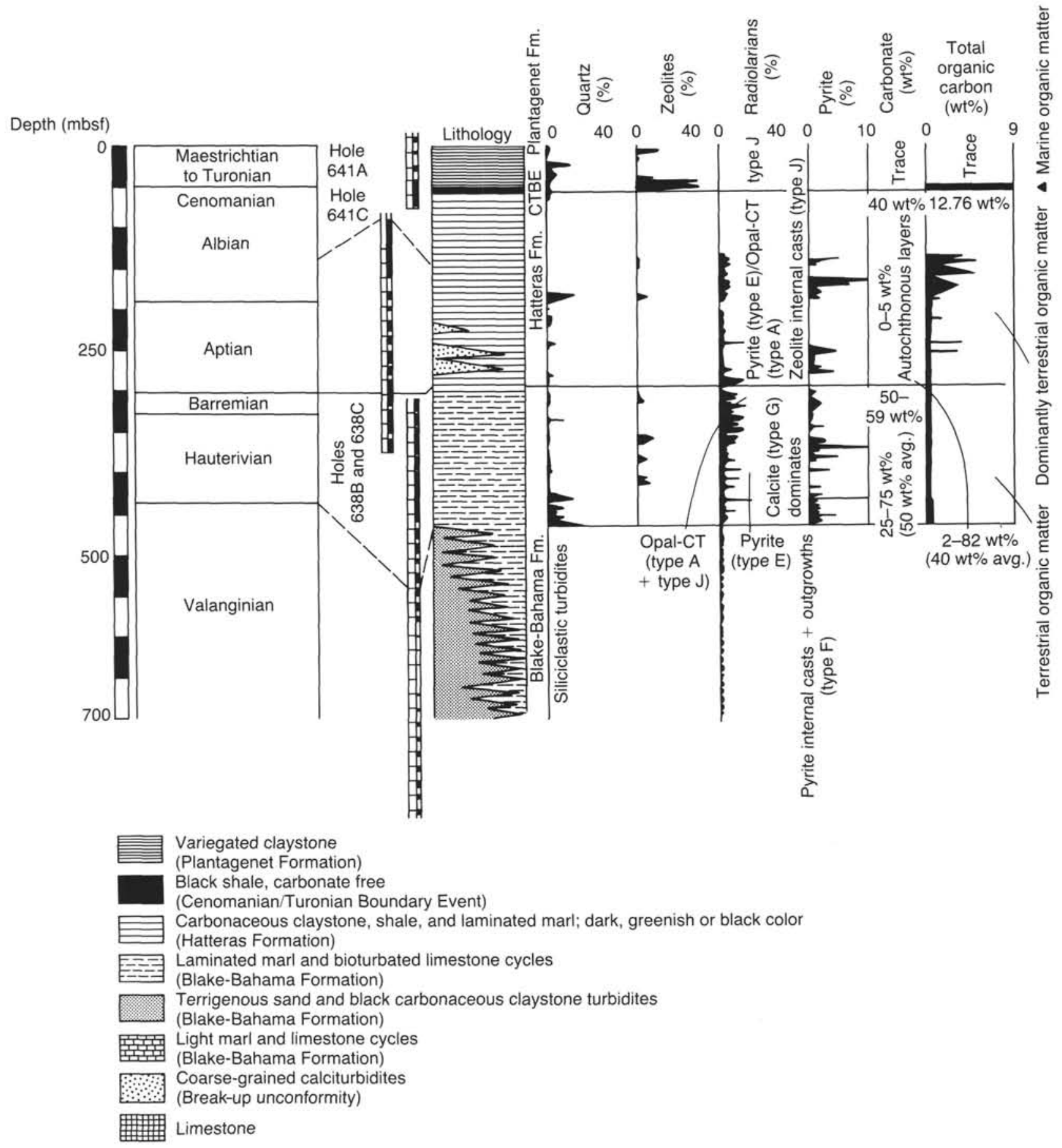

Figure 6. Composite summary of radiolarian abundance, preservation, alteration, and mineralization and accompanying minerals in relation to the host lithology of Sites 638 and 641 . n.r. = no record.

by calcite. Etching of some of the strongly cemented limestones (e.g., Cores 103-638B-21R and 103-638B-25R) shows that some of the radiolarian fauna $(<1 \%$ of the total radiolarians) are well preserved and replaced by opal-CT (and commonly filled with zeolite casts). The surfaces of these siliceous radiolarian tests are dotted with imprints of $\mathrm{CaCO}_{3}$ crystals from the surrounding sediment (Pl. 1, Figs. 3 and 5), and the skeletons consist of opal-CT in the form of regularly intertwinned blades (Pl. 1, Fig. 4, and Pl. 2, Fig. 7; Flörke et al., 1976). In the contact zones between the $\mathrm{CaCO}_{3}$ crystals and the radiolarian, the skeleton has a dense wall structure.
The original structure of the inner parts of opal-CT- (and quartz-) replaced radiolarian tests is commonly preserved (PI. 2, Figs. 3 and 4), whereas the surface, which is in contact with the sediment, shows not only imprints of crystals but also intense dissolution (Pl. 1, Fig. 7, and Pl. 2, Fig. 3). The distribution of the silica reveals a distinct pattern. The inner wall has a sharp boundary with the test fill, but the contact between the outer wall and the surrounding sediment is gradational (Pl. 2, Figs. 5 and 6). Additional vug-filling opal-CT lepispheres and quartz(?) are finely dispersed in the sediment (Pl. 2, Fig. 6, and Pl. 6, Fig. 1). 


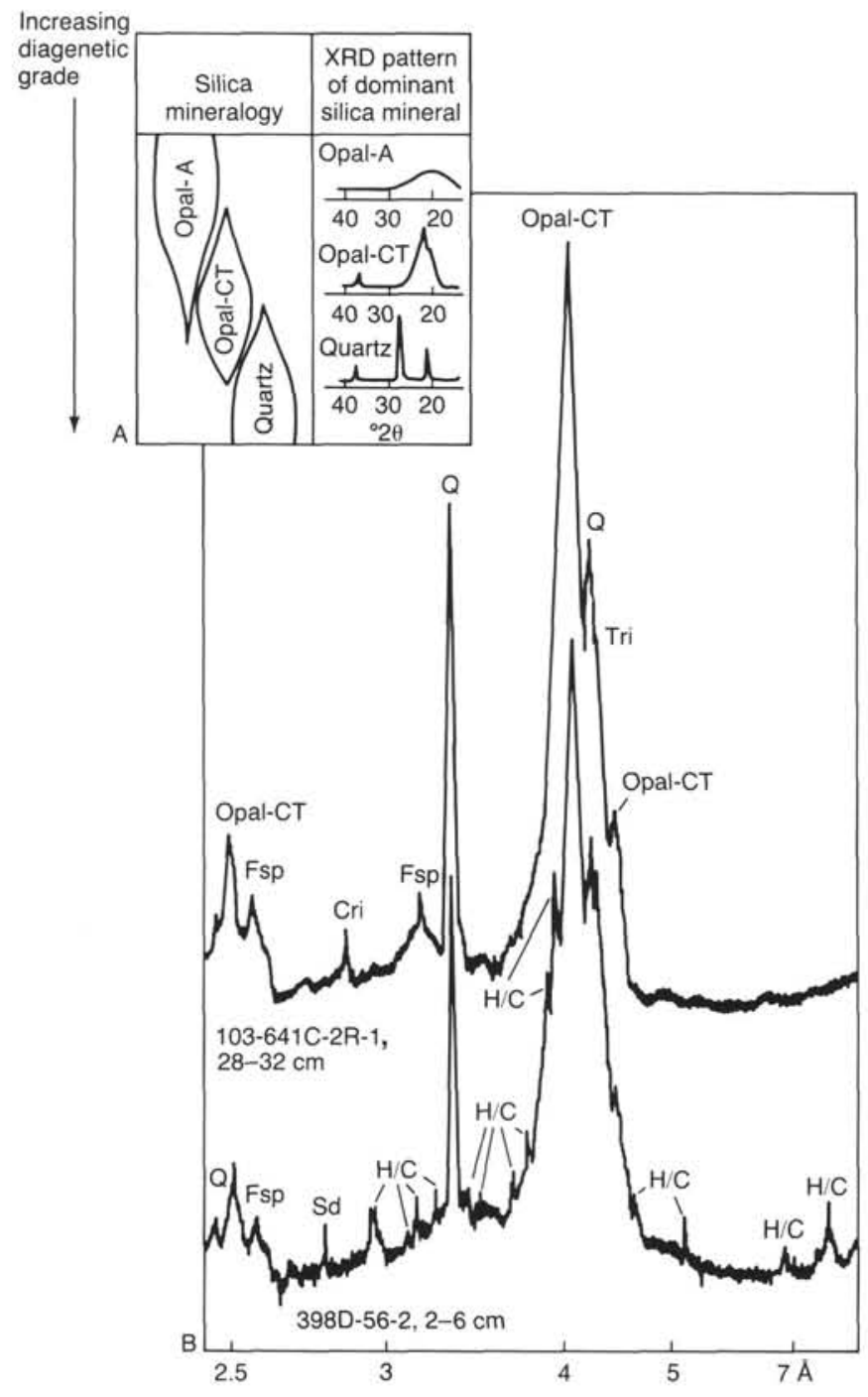

Figure 7. A. Generalized relation between mineralogy and diagenesis of siliceous rocks (from Pisciotto and Garrison, 1981). B. Powder diffraction of washed residues ( $>40 \mu \mathrm{m}$ ) of dark greenish claystone from the upper part of the Hatteras Formation (Sample 103-641C-2R-1, 28-32 $\mathrm{cm}$ ) and reddish claystone from the lower part of the Plantagenet Formation (Sample 398D-56-2, 2-6 cm). Opal-CT is the dominant replacement mineral. Quartz (Q) was not detected in radiolarian tests from thin-section studies of these samples; thus, quartz is likely of detrital origin. Feldspars (Fsp), siderite (Sd), ?cristobalite (Cri), and tridymite (Tri) are probably also detrital. $\mathrm{H} / \mathrm{C}=$ zeolite.

\section{Surface Dissolution (Corrosion) of Skeletons (Type B)}

The second major silica diagenetic feature is corrosion. Most silica-replaced radiolarians show different stages of intense surface dissolution. Skeletal attributes become modified (Pl. 2, Figs. 1 and 2), and the migration of the silica smooths the relief of the skeleton (Pl. 3, Figs. 3 and 5) and cements part of the adjacent host sediment, mainly clay minerals, but also biogenic components (Pl. 3, Fig. 6, of a coccolith replaced by silica). In the final stage, the surface of the skeleton is smooth (Pl. 3, Fig. 3 ), whereas the internal skeletal characteristics remain preserved (Pl. 3, Fig. 4).

The casts of the silica-replaced radiolarians include different minerals, with opal-CT common. In the carbonate-free Upper Cretaceous claystone, such test infillings are well preserved (Pl. 3, Fig. 7, and Pl. 4, Fig. 1), even where the skeleton is dissolved.
In general, dense opal-CT replaces the original skeletons to form radiolarian ghosts (Pl. 4, Fig. 2), whereas the inner wall shows lepispheres of opal-CT (Pl. 3, Fig. 1, and Pl. 4, Fig. 2), and some have an overgrowth of later formed clinoptilolite (Pl. 4, Fig. 1). Thin-section studies show that the most common silica phase in the samples studied is opal-CT. The presence of cryptocrystalline quartz is difficult to prove and is probably less common; however, both phases may occur in one skeleton. OpalCT-replaced radiolarians are well preserved in places (Pl. 1, Fig. 3 , and Pl. 3, Figs. 1 and 2) and are commonly filled with bladed lepispheres of opal-CT (Pl. 3, Fig. 2) or the remains of such lepispheres that now show the characteristic dense structure of microcrystalline quartz (Pl. 1, Fig. 6).

According to Kastner et al. (1977), the transformation from opal-A to opal-CT is a solution-redeposition mechanism, which would explain the common corrosion of the skeletons and precipitation of opal-CT lepispheres as internal casts. The composition of the solution and of the host sediments controls the rate of transformation from opal-A to opal-CT and finally to quartz. This transformation sequence takes place more rapidly in calcareous sediments than in clayey ones; therefore, opal-CT predominates in Mesozoic clayey sediments, such as the Plantagenet Formation and Hatteras Formation, whereas in carbonate sediments, such as the Tethyan Majolica and Scaglia pelagic limestones as well as in limestones from the Blake-Bahama Formation, quartz is common.

\section{Replacement of Radiolarians by Clinoptilolite (Type C)}

Clinoptilolite is widely distributed in the various lithologies studied, and it is common in all of the lithologic units except for the Valanginian-Hauterivian turbidite series of Holes 638B, 638C, and $640 \mathrm{~A}$. The most striking occurrences of clinoptilolite in and/or on radiolarians include (1) the replacement of radiolarian tests, (2) test infillings, and (3) overgrowths on silica-replaced skeletons.

The partial or complete transformation of radiolarians in different lithologies to a tabular euhedral mineral, indicated to be clinoptilolite by EDAX analysis and by the heating test of Mumpton (1960) (Fig. 3), has been described from several Atlantic sites for Cretaceous and younger strata (Mélières, 1979; Riech and von Rad, 1979a; Otsuka, 1985).

The processes of zeolitization differ because of the different host lithologies. In the Upper Cretaceous zeolitic clay of Hole 603B (Cores 603B-26 and 603B-33) most ( $\sim 99 \%)$ of the fauna has been transformed to clinoptilolite (Figs. 3 and 8 and Pl. 5, Figs. 1 and 2). In addition, even the remaining $1 \%$ of well-preserved radiolarians consists of clinoptilolite and only rarely of opal-CT (intermediate steps between opal-CT or quartz and clinoptilolite replacements) (Pl. 4, Fig. 6).

Common internal casts are also made of clinoptilolite type $\mathrm{J}$ (Pl. 5, Fig. 2, for SEM micrograph; Appendix A-1 for EDAX analysis).

In many samples, not only does a replacement of the original skeleton exists, but coarser clinoptilolite crystals also infill the tests (PI. 5, Figs. 2 and 3). Some of the original test structures are still visible and skeletal attributes can also be seen as negative imprints on zeolite internal casts (compare Pl. 5, Fig. 4, with Pl. 8, Fig. 1), but the crystal shape of the clinoptilolite is always present. Moreover, this type of zeolite formation is rarely seen in lithologies other than the Upper Cretaceous zeolitic claystone of Hole 603B (Appendix B), but definite observations have been made in a few radiolarians from Hole 638B (Section 103-638B-22R, CC). Zeolites generally form differently in other lithologies. For example, in the limestone and marlstone of the upper part of the Blake-Bahama Formation in Holes 638B and $640 \mathrm{~A}$, the original tests were dissolved and the cavities filled with clinoptilolite crystals (Pl. 5, Fig. 5). Framboidal pyrite at 


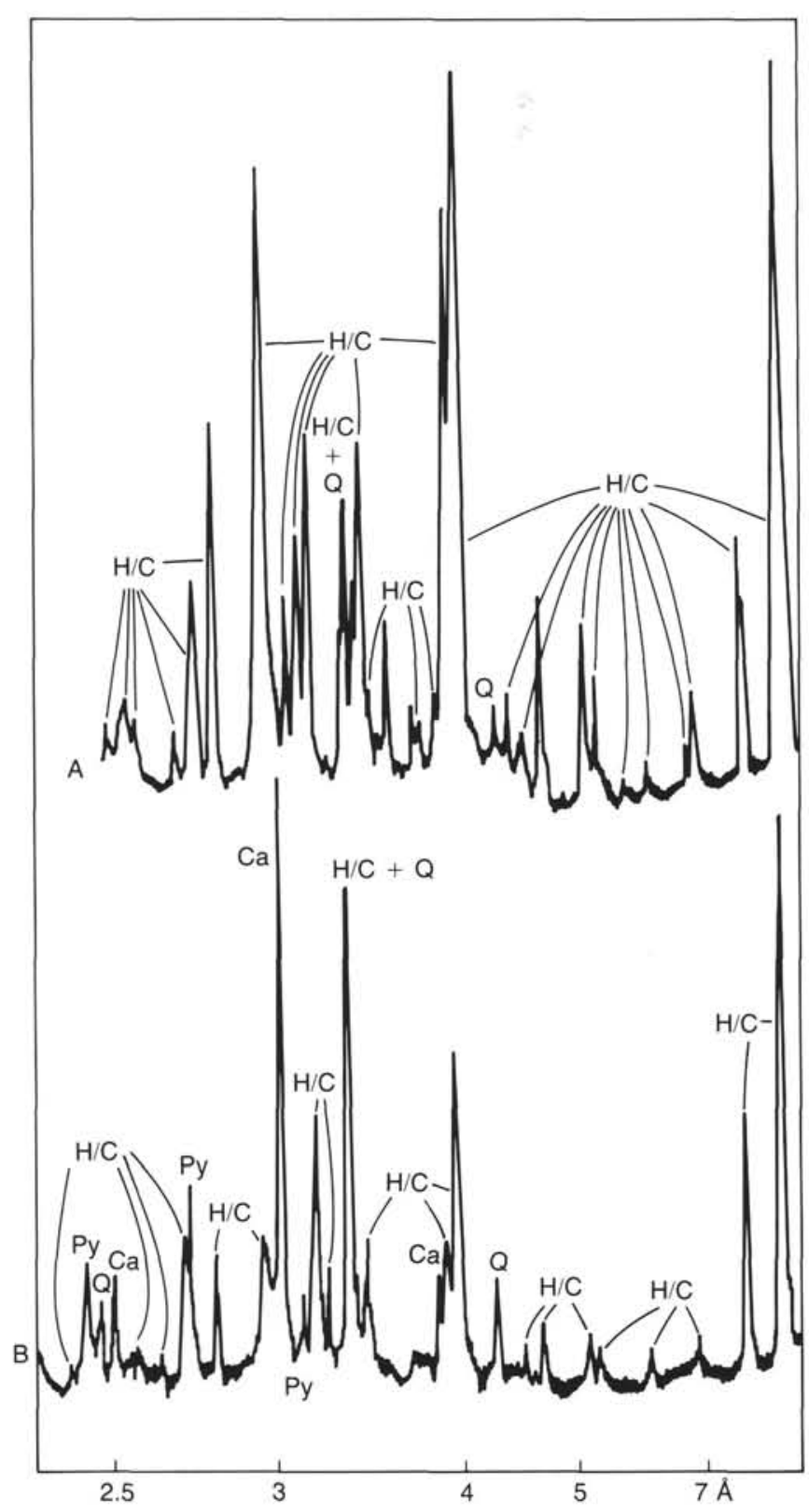

Figure 8. Powder diffraction patterns of washed residues ( $>40 \mu \mathrm{m})$. A. Zeolitic claystone consisting of $>99 \%$ radiolarians and internal casts from the Plantagenet Formation (Sample 603B-26-1, 90-93 cm). Radiolarians are replaced by clinoptilolite (H/C) (see Fig. 3), and quartz (Q) is likely of detrital origin. B. Laminated marlstone with dominantly pyrite-replaced radiolarians (Py) from the upper part of the Blake-Bahama Formation (Sample 103-638B-22R-1, 14-18 cm). Zeolite (H/C), which was seen in thin sections, is also detected by XRD. Some of the quartz is probably derived from partially quartz-replaced radiolarian tests; the rest of the quartz is of detrital origin. Calcite $(\mathrm{Ca})$ is from sediment particles.

the boundaries of the former tests may be a degradation product of the radiolarian organic parts. In the Aptian-Albian black shale/gray-green shale couplets, zeolitization is not uniform. Zeolite-replaced radiolarians are only rarely seen in Holes 398D and $641 \mathrm{C}$, but large crystals of clinoptilolite infill opal-CT-replaced skeletons (Pl. 4, Figs. 3-5). Remains of the silica from the primary opal-A skeleton are opal-CT blades on "pseudolepispheres" scattered in the sediment (Pl. 6, Fig. 1; EDAX analyses in Appendix A-2 = material surrounding the lepi- spheres and in Appendix A-3 = lepisphere formed by a Ca-, K-, and $\mathrm{Fe}$-rich clay mineral-? smectite).

Overgrowth of clinoptilolite is also common (Pl. 4, Fig. 7). Furthermore, clinoptilolite is commonly associated with radiolarian ghosts in thin sections. The clinoptilolite forms the nuclei of the ghosts, which are composed of spherical clay-mineral replacements of radiolarian tests (Pl. 5, Fig. 6, and Pl. 7, Fig. 6).

The occurrence of clinoptilolite in deep-sea sediments is common (Kastner and Stonecipher, 1978; Stonecipher, 1978). These occurrences are characterized as having no crystals $>45 \mu \mathrm{m}$ (average $10-20 \mu \mathrm{m}$ ), the chemistry is always characterized by a high silica content, and the $\mathrm{Ca}$ content in clinoptilolites from carbonate-bearing sediment and chalk is not as low (in some places the percentage of $\mathrm{Ca}$ plus $\mathrm{Mg}$ may be high enough to call the mineral heulandite). In the studied North Atlantic samples, the $\mathrm{Ca}$ content of the clinoptilolite is low (even in carbonate-bearing sediments), $\mathrm{Mg}$ was not detected, and the mineral clinoptilolite is inferred (see also Fig. 3). Mélières (1979) studied comparable sediments in the North Atlantic and confirmed that the zeolites are true clinoptilolites.

The formation of clinoptilolite is not yet fully understood. Most authors suggest an alteration of volcanic material (or its alteration products) or biogenic silica as precursor to form clinoptilolite (compilation in Kastner and Stonecipher, 1978). However, Berger and von Rad (1972) described the precipitation of clinoptilolite from pore solutions in an ash-free pelagic sediment. Authigenic silicates such as zeolites are formed if sufficient aluminum, alkali, and alkali earth ions are available in the pore water and if either the silica contribution is below the saturation value for opal-CT or the available silica decreases considerably as a result of the common formation of opal-CT. Euhedral clinoptilolite prisms commonly constitute the latest phase filling radiolarian tests after the formation of opal-CT lepispheres (Pl. 4, Fig. 1). Clinoptilolite can also form during an increase of the interstitial-water silica concentration before opalCT precipitation (Riech and von Rad, 1979a) (Pl. 4, Fig. 7). Similar to opal-CT, massive clinoptilolite can also completely replace the radiolarian test ( $\mathrm{Pl}$. 4, Fig. 6), including delicate skeletal attributes.

According to Gottardi and Galli (1985), in comparison to the major zeolite mineral in deep-sea sediments (phillipsite), clinoptilolites are more common in carbonate-bearing sediments (with high sedimentation rates) than in clayey deposits (with low sedimentation rates). Clinoptilolite is also more common in Atlantic sediments, whereas phillipsite is more common in the Pacific. In the sections we studied, clinoptilolite is common in nearly all of the major lithologies, whether calcareous or not. It is common in Lower Cretaceous strata with comparably high sedimentation rates, as well as in Upper Cretaceous strata with low sedimentation rates. Furthermore, no volcanic relicts have been found. This relationship also exists in several coeval and lithologically comparable sites in the North Atlantic (Mélières, 1979; Otsuka, 1985). From SEM and thin-section studies and from residues, it is clear that clinoptilolite is usually associated more with partially dissolved siliceous debris remains than with volcanogenic material, an observation first discussed in detail by Hein et al. (1978).

According to Heath (1974), the occurrence of volcanic material with siliceous deposits in the geologic record does not reflect a cause-effect relation, but rather the association of volcanism with the same tectonic processes that modify oceanographic and depositional environments so as to induce high productivity of radiolarians and preservation of the tests.

\section{Replacement of Radiolarians or Clinoptilolite by Pyrite (Types D + E)}

Various replacements of radiolarian skeletons by pyrite are the most common form of diagenesis in Holes 638B and 640A. 
The diagenesis includes (1) replacement of opal-A by massive pyrite formation of pyrite internal casts and dissolution of the primary test (type E) and (2) replacement of clinoptilolite internal casts by pyrite (type D).

Pyrite replacement depends on the age of the deposits. Pyrite replacement begins with minute pyrite crystals in lower $\mathrm{Al}$ bian deposits (rare at Hole 398D and common at Hole 641C) and increases in abundance to complete replacement of the original siliceous tests downsection in the Blake-Bahama Formation (Holes 603B, 638B,C, 640A, and 641C).

Replacement of the primary skeletal mineral by massive pyrite in places yields well-preserved faunas (Pl. 6, Fig. 2). The pyrite-replaced skeletons are filled with coarse calcite in the nannofossil-rich limestone and marlstone facies. The pyrite replacement preserves even the most delicate skeletal elements (PI. 6, Fig. 3). An incipient recrystallization locally develops crystal faces of pyrite. Not only are the skeletons replaced by pyrite, but pyrite also forms internal casts within one specimen ( $\mathrm{Pl}$. 6 , Fig. 4, and Appendix A-4).

Solution pits formed on the surface of pyrite-replaced skeletons (Pl. 6, Fig. 5). A step-by-step replacement of the pyrite-replaced skeletons by framboidal pyrite was also commonly observed (Pl. 6, Fig. 5). Final recrystallization was to coarse crystalline pyrite. Casts of radiolarians made up entirely of pyrite framboids are a final diagenetic feature (Pl. 7, Fig. 7), only rarely showing negative images of the former skeletal morphology (Pl. 6, Fig. 6). In places, pyrite-replaced radiolarians are overgrown by coarse, well-developed pyrite crystals (Pl. 7, Fig. 2).

The replacement process of the primary skeletal mineral by pyrite is puzzling. An intermediate mineralogic stage prior to pyrite replacement was never observed. In the gray-green claystone alternating with black shale of the Hatteras Formation, some of the silica-replaced radiolarians show a metallic luster of type H. SEM studies reveal this luster to be created by pyrite in two forms:

1. Tiny patches of pyrite crystals on the partly dissolved silica-replaced skeletons (Pl. 7, Fig. 10; Appendix A-5 for the skeleton and Appendix A-6 for the crystals). It is unlikely that this form of pyrite formation finally led to well-preserved pyrite-replaced radiolarians.

2. Fine pyrite dispersed within the siliceous skeleton. This pyrite was mapped by EDAX analysis but was not visible as discrete grains with the SEM. Long-term treatment of the fauna with $\mathrm{H}_{2} \mathrm{O}_{2}$ changes them to a rusty color because of oxidation of the finely dispersed pyrite. This latter form of pyrite may be an early stage in the replacement of the primary skeletal mineralogy.

Another puzzling phenomenon observed is the monospecific replacement by opal-CT, whereas all other forms are replaced by pyrite of type $\mathrm{K}$ (see Pl. 9, Fig 1. in Thurow, this volume).

\section{Formation of Pyrite Internal Casts and Dissolution of the Primary Skeleton (Type F)}

Pyrite internal casts are the most common form of preservation of radiolarians in the clastic facies of the Blake-Bahama Formation. In general, the casts clearly reflect the primary skeleton (Pl. 7, Fig. 7), but they commonly show pyrite recrystallization and overgrowth (Pl. 7, Figs. 3 and 11, and Pl. 8, Fig. 1). The internal casts formed from a step-by-step replacement and recrystallization that produced pyrite with crystal faces (Pl. 8, Fig. 1); finally, skeletal features were engulfed by the growing pyrite crystals (Pl. 7, Fig. 11).

Rarely, pyrite-replaced skeletons exhibit internal casts of clinoptilolite or zeolite growth in the internal cavity (Fig. 8, Ap- pendix A-7 EDAX analysis of abundant pyrite, and Pl. 7, Figs. 5 and 11$)$.

Castings with framboidal pyrite (Pl. 7, Fig. 8) in a manner similar to the framboidal pyrite described as infillings of diatoms by Schallreuter (1984), as well as recrystallization of massive pyrite to framboidal pyrite ( $\mathrm{Pl}$. 7, Fig. 1), are also commonly observed in dark laminites of the Blake-Bahama Formation.

In many samples, pyrite pseudomorphs after clinoptilolite have been observed. Radiolarian casts are formed of euhedral crystals typical of clinoptilolite (PI. 7, Fig. 4). EDAX analysis of single crystals indicates that these crystals are pyrite (Pl. 8, Fig. 2, and Appendix A-8).

In Hole 638B, coarse "clinoptilolite" casts infilling pyrite-replaced radiolarians reveal a puzzling mineralogy. EDAX analysis shows that even these "clinoptilolite" crystals contain a remarkable amount of pyrite that is not visible with the SEM (Appendix A-9) - probably a first step of in-situ replacement of the zeolite by pyrite.

The precise mechanism of pyrite replacement and formation of framboidal pyrite is still unknown (Schallreuter, 1984). Pyrite formation is obviously linked with the presence of organic matter providing a favorable environment for anaerobic bacteria in the sediments of the Hatteras Formation and Blake-Bahama Formation. According to Berner (1970), however, the essential requirements for the production of microcrystalline pyrite in normal marine waters include not only the presence of organic matter for the metabolism of sulfate-reducing bacteria but also the diffusion of sulfate into the sediment (Criddle, 1974) or to the radiolarian replaced by pyrite. This is supported by the finding in this study that in sediment bearing pyrite-replaced radiolarians, the pyrite is always finely dispersed, chiefly as framboids. Furthermore, the formation of an internal cast made of pyrite requires more sulfur and iron than provided by the organic matter of the radiolarian. Therefore, sulfur and iron must also diffuse into the radiolarian from outside sources.

It is not known why the black shales of the CTBE and in parts of the Hatteras Formation are devoid of pyrite-replaced skeletons.

\section{Calcite Replacement of Radiolarians (Type G)}

Replacement of radiolarian skeletons by calcite is by far the most common process in the pelagic nannofossil marlstone and limestone of the Blake-Bahama Formation. Thin-section studies show that, in general, the entire skeleton is replaced by coarse crystalline calcite, preserving only the gross morphology and not the delicate skeletal elements (Pl. 8, Fig. 5). Replacement was by dissolution of the primary skeleton and precipitation of coarse calcite casts in the cavity. At the boundary between the calcareous host sediment and the siliceous skeleton, calcite tends to form coarse crystals growing into the central radiolarian cavities (Pl. 8, Fig. 3), which led to a successive destruction of the skeleton (PI. 8, Fig. 4). The skeletons dissolved and the silica migrated into the surrounding sediment (PI. 2, Fig. 6), leaving behind a cavity filled with continuously coarser-grained calcite crystals (Pl. 8, Fig. 6).

A comparable process is the formation of calcitic internal casts within pyrite-replaced radiolarians, which are common in the bioturbated nannofossil limestone of the Blake-Bahama Formation. Replacement of pyrite by calcite was not observed.

Replacement of radiolarians by calcite is also common in Cretaceous pelagic calcareous deposits in onshore outcrops, such as the Upper Cretaceous Scaglia of the circum-Mediterranean fold belts or the Majolica, the Tethyan equivalent of the BlakeBahama Formation. These deposits contain large quantities of radiolarians that are replaced by quartz in some layers, depending on their original abundance in the sediment, whereas in 
most layers, the radiolarians dissolved and calcite casts were produced. The silica released by replacement migrated and formed local chert layers or nodules. This process was only rarely observed in the samples studied. A first stage is open cavity growth of chalcedony (figured in pl. 8, figs. 3 and 4, of Thein and von Rad, 1987). A similar growth of chalcedony was observed in thin sections from the pelagic limestones at Hole 638B (Cores 103-683B-21R and 103-638B-25R). This probably led to the formation of Lower Cretaceous quartz cherts in the North Atlantic, as described by Riech and von Rad (1979a).

\section{DISCUSSION (COMPARE WITH APPENDIX B)}

Two different types of depositional environments leading to the different lithologies observed are known from the Cretaceous North Atlantic: oxygenated environments in the Lower and Upper Cretaceous and oxygen-deficient environments in the middle Cretaceous. The diagenetic history of the radiolarian faunas reflects these differences in environmental conditions.

Radiolarians from Upper Cretaceous calcium carbonate-free claystones deposited in an oxic environment are rarely recorded; they may have been completely removed by dissolution. Yet, in the strata deposited during two major Late Cretaceous oceanic events (CTBE and the Lower Campanian Biosiliceous Event), radiolarian faunas are common and replaced by coarse-grained zeolites or opal-CT. Radiolarians from the Hauterivian-Barremian pelagic limestone are replaced by microspar and, only in places of intense bioturbation, by pyrite.

The diagenetic history of radiolarians from sediments deposited in oxygen-depleted or anoxic environments is different from that of radiolarians deposited in oxic environments. Radiolarians are replaced by silica or zeolite in the black shale and alternating gray-green claystone. Black shales (with kerogen dominantly type II) contain radiolarians replaced generally by silicates, similar to onshore occurrences observed by Thurow and Kuhnt (1986) and Thurow (1987). Although the anaerobic depositional environment of this sediment type would apparently have been most favorable for skeleton replacement by pyrite, no pyritized skeletons were found.

In the black shale and alternating gray-green claystone of the Hatteras Formation, radiolarians are again preferably replaced by opal-CT (commonly with zeolite internal casts). At Hole $641 \mathrm{C}$, radiolarians in the black shale sequence are frequently replaced by pyrite, although there are still opal-CT-replaced forms (Appendix B). At Hole 398D, radiolarians in organic-carbonrich sediments show lusters of pyrite/limonite, which were not observed in the organic-carbon-poor layers.

The allochthonous dark and organic-carbon-rich marls (with kerogen dominantly type III) of the clastic Valanginian and Hauterivian sequence also provide an $\mathrm{O}_{2}$-depleted, or anoxic, microchemical environment for the radiolarians, which are replaced by pyrite. All of the faunas were redistributed, and it is not clear as to whether the radiolarians were transformed into pyrite at the drill site or if they were pyritized prior to redistribution.

\section{ACKNOWLEDGMENTS}

I thank the Ocean Drilling Program for the invitation to participate in Leg 103 aboard the JOIDES Resolution and to obtain samples from Sites 638,640 , and 641 . The National Science Foundation provided the samples from DSDP Leg 47B (Hole 398D) and Leg 93 (Hole 603B). The technical assistance of Horst Hüttemann (Tübingen; SEM and EDAX analysis) is appreciated. This chapter greatly benefited from the reviews and helpful criticism by Dr. von Rad (Hannover) and two anonymous reviewers. This work was supported by the German D.F.G. Grant Wi $112-25$.

\section{REFERENCES}

Arthur, M. A., and Natland, J. H., 1979. Carbonaceous sediments in the North and South Atlantic: the role of salinity in stable stratifica- tion of Early Cretaceous basins. In Talwani, M., Hay, W., and Ryan, W.B.F. (Eds.), Deep Drilling Results in the Atlantic Ocean: Continental Margins and Paleoenvironment: Am. Geophys. Union, Maurice Ewing Ser., 3:375-401.

Berger, W. H., and von Rad, U., 1972. Cretaceous and Cenozoic sediments from the Atlantic Ocean. In Hayes, D. E., Pimm, A. C., et al., Init. Repts. DSDP, 14: Washington (U.S. Govt. Printing Office), 787-954.

Berner, R. A., 1970. Sedimentary pyrite formation. Am. J. Sci., 268:123.

Bramlette, M. N., 1946. The Monterey Formation of California and the origin of its siliceous rocks. Geol. Surv. Prof. Pap. (U.S.), 213.

Brumsack, H.-J., and Thurow, J., 1986. The geochemical facies of black shales from the Cenomanian/Turonian Boundary Event. In Degens, E. T., Meyers, P. A., and Brassell, C. (Eds.), Biogeochemistry of Black Shales: Mitt. Geol. Staatsinst. Hamburg, 60:247-265.

Chamley, H., 1979. North Atlantic clay sedimentation and paleoenvironment since the Late Jurassic. In Talwani, M., Hay, W., and Ryan, W.B.F. (Eds.), Deep Drilling Results in the Atlantic Ocean: Continental Margins and Paleoenvironment: Am. Geophys. Union, Maurice Ewing Ser., 3:342-361.

Chamley, H., and Debrabant, P., 1984. Paleoenvironmental history of the North Atlantic region from mineralogical and geochemical data. Sediment. Geol., 40:151-167.

Chamley, H., and Deconinck, J.-F., 1985. Expression de l'évolution géodynamique des domaines nordatlantique et subalpin au Mésozoïque supérieur, d'après les successions sédimentaires argileuses. $C$. R. Acad. Sci. Ser. 2: 300:1007-1012.

Criddle, A. J., 1974. A preliminary description of microcrystalline pyrite from the nannoplankton ooze at Site 251, SW Indian Ocean. In Davies, T. A., Luyendyk, B. P., et al., Init. Repts. DSDP, 26: Washington (U.S. Govt. Printing Office), 603-611.

de Graciansky, P. C., Brosse, E., Deroo, G., Herbin, J.-P., Montadert, L., Müller, C., Sigal, J., and Schaaf, A. 1982. Les formations d'âge crétacé de l'Atlantique nord et leur matière organique: paléogéographie et milieux de dépôt. Rev. Inst. Fr. Pet., 37:275-336.

Flörke, O. W., Hollmann, R., von Rad, U., and Rösch, H., 1976. Intergrowth and twinning in opal-CT lepispheres. Contrib. Mineral. Petrol., 58:235-242.

Gottardi, G., and Galli, E., 1985. Natural Zeolites: Berlin (Springer).

Heath, G. R., 1973. Cherts from the Eastern Pacific, Leg 16, Deep Sea Drilling Project. In van Andel, T. H., and Heath, G. R., et al., Init. Repts. DSDP, 16: Washington (U.S. Govt. Printing Office), 609613.

1974. Dissolved silica and deep-sea sediments. In Hay, W. W. (Ed.), Studies in Paleo-Oceanography: Spec. Publ. Soc. Econ. Paleontol. Mineral., 20:77-93.

Heath, G. R., and Moberly, R., 1971. Cherts from the Western Pacific, Leg 7, Deep Sea Drilling Project. In Winterer, E. L., and Riedel, W. R., et al., Init. Repts. DSDP, 7, Pt. 1: Washington (U.S. Govt. Printing Office), 991-1007.

Hein, J. R., Scholl, D. W., Barron, J. A., Jones, M. G., and Miller, J., 1978. Diagenesis of Late Cenozoic diatomaceous deposits and formation of the bottom simulating reflector in the southern Bering Sea. Sedimentology, 25:155-181.

Hein, J. R., Vallier, T. L., and Allan, M. A., 1981. Chert petrology and geochemistry mid-Pacific mountains and Hess Rise, Deep Sea Drilling Project Leg 62. In Thiede, J., and Vallier, T. L., et al., Init. Repts. DSDP, 62: Washington (U.S. Govt. Printing Office), 711748.

Herbin, J.-P., Montadert, L., Müller, C., Gomez, R., Thurow, J., and Wiedmann, J., 1986. Organic-rich sedimentation at the Cenomanian-Turonian Boundary in oceanic and coastal basins in the North Atlantic and Tethys. In Summerhayes, C. P., and Shackleton, N. J. (Eds.), North Atlantic Palaeooceanography: Spec. Publ. Geol. Soc. London, 21:389-422.

Iijima, A., Hein, J. R., and Siever, R. (Eds.), 1983. Siliceous Deposits in the Pacific Region: Amsterdam (Elsevier).

Jansa, L. F., Enos, P., Tucholke, B. E., Gradstein, F. M., and Sheridan, R. E., 1979. Mesozoic-Cenozoic sedimentary formations of the North American Basin; western North Atlantic. In Talwani, M., Hay, W., and Ryan, W.B.F. (Eds.), Deep Drilling Results in the Atlantic Ocean: Continental Margins and Paleoenvironment: Am. Geophys. Union, Maurice Ewing Ser., 3:1-57.

Jones, J. B., and Segnit, E. R., 1971. The nature of opal. I. Nomenclature and constituent phases. J. Geol. Soc. Aust., 18:57-68. 
Kastner, M., and Keene, J. B., 1975. Diagenesis of pelagic siliceous oozes. Int. Sedimentol. Congr., 9th, 7:89-98.

Kastner, M., Keene, J. B., and Gieskes, J. M., 1977. Diagenesis of siliceous oozes. I. Chemical controls on the rate of opal-A to opal-CT transformation-an experimental study. Geochim. Cosmochim. Acta, 41:1041-1059.

Kastner, M., and Stonecipher, S. A., 1978. Zeolites in pelagic sediments of the Atlantic, Pacific and Indian Oceans. In Sand, L. B., and Mumpton, F. A. (Eds.), Natural Zeolites: Oxford (Pergamon), 199200.

Keene, J. B., 1975. Cherts and porcellanites from the North Pacific, DSDP Leg 32. In Larson, R. L., Moberly, R., et al., Init. Repts. DSDP, 32: Washington (U.S. Govt. Printing Office), 429-507.

Kuhnt, W., Thurow, J., Wiedmann, J., and Herbin, J.-P., 1986. Oceanic anoxic conditions around the Cenomanian/Turonian Boundary and the response of the biota. In Degens, E. T., Meyers, P. A., and Brassell, C. (Eds.), Biogeochemistry of Black Shales: Mitt. Geol. Staatsinst. Hamburg, 60:205-246.

Lancelot, Y., 1973. Chert and silica diagenesis in sediments from the Central Pacific. In Winterer, E. L., and Ewing, J. I., et al., Init. Repts. DSDP, 17: Washington (U.S. Govt. Printing Office), 377405.

McIver, R., 1975. Hydrocarbon occurrences from JOIDES Deep Sea Drilling Project. Proc. World Pet. Congr., 9th, 269-280.

Mélières, F., 1979. Mineralogy and geochemistry of selected Albian sediments from the Bay of Biscay, Deep Sea Drilling Project Leg 48. In Montadert, L., Roberts, D. G., et al., Init. Repts. DSDP, 48: Washington (U.S. Govt. Printing Office), 855-875.

Mumpton, F. A., 1960. Clinoptilolite redefined. Am. Mineral., 45:351369.

Murata, K. J., and Larson, R. R., 1975. Diagenesis of Miocene siliceous shales, Temblor Range, California. J. Res. U.S. Geol. Surv., 3:553566.

Ogg, J. G., Haggerty, J. A., Sarti, M., and von Rad, U., 1987. Lower Cretaceous pelagic sediments of Deep Sea Drilling Project Site 603, western North Atlantic: a synthesis. In van Hinte, J. E., Wise, S. W., Jr., et al., Init. Repts. DSDP, 93: Washington (U.S. Govt. Printing Office), 1305-1331.

Otsuka, K., 1985. Silicified sediments and silica diagenesis in the Goban Spur area of the Northeast Atlantic, Leg 80. In de Graciansky, P. C., Poag, C. W., et al., Init. Repts. DSDP, 80: Washington (U.S. Govt. Printing Office), 1081-1099.

Pisciotto, K. A., 1981. Distribution, thermal histories, isotopic compositions, and reflection characteristics of siliceous rocks recovered by the Deep Sea Drilling Project. In Warne, J. E., Douglas, R. G., and Winterer, E. L. (Eds.), The Deep Sea Drilling Project: A Decade of Progress: Spec. Publ. Soc. Econ. Paleontol. Mineral., 32:129-148.

Pisciotto, K. A., and Garrison, R. E., 1981. Lithofacies and depositional environments of the Monterey Formation, California. In Garrison, R. E., and Douglas, R. G. (Eds.), The Monterey Formation and Related Siliceous Rocks of California: Spec. Publ. Soc. Econ. Paleontol. Mineral., Pacific Sect., 15:97-122.

Riech, V., and von Rad, U., 1979a. Silica diagenesis in the Atlantic Ocean: diagenetic potential and transformations. In Talwani, M., Hay, W., and Ryan, W.B.F. (Eds.), Deep Drilling Results in the Atlantic Ocean: Continental Margins and Paleoenvironment: Am. Geophys. Union, Maurice Ewing Ser., 3:315-340.

$1979 \mathrm{~b}$. Eocene porcellanites and Early Cretaceous cherts from the western North Atlantic Basin. In Tucholke, B. E., Vogt, P. R., et al., Init. Repts. DSDP, 43: Washington (U.S. Govt. Printing Office), 437-455.

Sarti, M., and von Rad, U., 1987. Early Cretaceous turbidite sedimentation at Deep Sea Drilling Project Site 603, off Cape Hatteras (Leg 93). In van Hinte, J. E., Wise, S. W., Jr., et al., Init. Repts. DSDP, 93: Washington (U.S. Govt. Printing Office), 891-940.

Schallreuter, R., 1984. Framboidal pyrite in deep-sea sediments. In Hay, W. W., Sibuet, J.-C., et al., Init. Repts. DSDP, 75: Washington (U.S. Govt. Printing Office), 875-891.

Schlanger, S. O., Arthur, M. A., Jenkyns, H. C., and Scholle, P. A., 1987. The Cenomanian-Turonian Anoxic Event, I: stratigraphy and distribution of organic carbon-rich beds and the marine excursion. In Brooks, J., and Fleet, A. (Eds.), Marine Petroleum Source Rocks: Spec. Publ. Geol. Soc. London, 26:371-399.

Shipboard Scientific Party, 1979. Site 398. In Sibuet, J.-C., Ryan, W.B.F., et al., Init. Repts. DSDP, 47, Pt. 2: Washington (U.S. Govt. Printing Office), 25-231.

1987a. Site 603. In van Hinte, J. E., Wise, S. W., Jr., et al., Init. Repts. DSDP, 93: Washington (U.S. Govt. Printing Office), 25-276.

1987b. Site 638. In Boillot, G., Winterer, E. L., et al., Proc. ODP, Init. Repts., 103: College Station, TX (Ocean Drilling Program), 221-407.

1987c. Site 640. In Boillot, G., Winterer, E. L., et al., Proc. ODP, Init. Repts., 103: College Station, TX (Ocean Drilling Program), 533-569.

1987d. Site 641. In Boillot, G., Winterer, E. L., et al., Proc. ODP, Init. Repts., 103: College Station, TX (Ocean Drilling Program), 571-649.

Sigal, J., 1979. Chronostratigraphy and ecostratigraphy of Cretaceous formations recovered on DSDP Leg 47B, Site 398. In Sibuet, J.-C., Ryan, W.B.F., et al., Init. Repts. DSDP, 47, Pt. 2: Washington (U.S. Govt. Printing Office), 287-326.

Stein, R., Rullkötter, J., and Welte, D., 1986. Accumulation of organiccarbon-rich sediments in the Late Jurassic and Cretaceous Atlantic Ocean-a synthesis. Chem. Geol., 56:1-32.

Stonecipher, S. A., 1976. Origin, distribution and diagenesis of phillipsite and clinoptilolite in deep-sea sediments. Chem. Geol., 17:307318.

1978. Chemistry of deep-sea phillipsite, clinoptilolite and host sediments. In Sand, L. B., and Mumpton, F. A. (Eds.), Natural Zeolites: Oxford (Pergamon), 221-234.

Thein, J., and von Rad, U., 1987. Silica diagenesis in continental rise and slope sediments off eastern North America (Sites 603 and 605, Leg 93; Sites 612 and 613, Leg 95). In Poag, C. W., Watts, A. B., et al., Init. Repts. DSDP, 95: Washington (U.S. Govt. Printing Office), 501-525.

Thurow, J., 1987. Die kretazischen Turbiditserien im Gibraltarbogens: bindeglied zwischen atlantischer und tethyaler Entwicklung [Ph.D. dissert.]. Univ. Tübingen.

Thurow, J., and Kuhnt, W., 1986. Mid-Cretaceous of the Gibraltar Arch area. In Summerhayes, C. P., and Shackleton, N. J. (Eds.), North Atlantic Palaeooceanography: Spec. Publ. Geol. Soc. London, 21:423-445.

Thurow, J., Kuhnt, W., and Wiedmann, J., 1982. Zeitlicher und paläogeographischer Rahmen der Phthanit- und black shale-sedimentation in Marokko. Neues Jahrb. Geol. Palaeontol. Abh., 165:147176.

von Rad, U., and Botz, R., 1987. Authigenic Fe-Mn carbonates in Cretaceous and Tertiary sediments of the continental rise off eastern North America, Deep Sea Drilling Project Site 603. In van Hinte, J. E., Wise, S. W., Jr., et al., Init. Repts. DSDP, 93: Washington (U.S. Govt. Printing Office), 1061-1077.

von Rad, U., Riech, V. and Rösch, H., 1977. Silica diagenesis in continental margin sediments off northwest Africa. In Lancelot, Y., Seibold, E., et al., Init. Repts. DSDP, 41: Washington (U.S. Govt. Printing Office), 879-905.

von Rad, U., and Rösch, H., 1974. Petrography and diagenesis of deepsea cherts from the central Atlantic. Spec. Publ. Int. Assoc. Sedimentol., 1:327-347.

von Rad, U., and Sarti, M., 1986. Early Cretaceous 'events' in the evolution of the eastern and western North Atlantic continental margins. Geol. Rundsch., 75:139-158.

Wise, S. W., Jr., and Weaver, F. M., 1974. Chertification of oceanic sediments. Spec. Publ. Int. Assoc. Sedimentol., 1:301-326.

Date of initial receipt: 30 March 1987

Date of acceptance: 29 February 1988

Ms 103B-182 
APPENDIX A

EDAX Analysis of Selected Alteration Features

Gold palladium was used for coating; thus $\mathrm{Au}$ and $\mathrm{Pd}$ peaks are not relevant for the analysis. $\mathrm{AL}=$ aluminium; $\mathrm{SI}=\mathrm{SiO}_{2} ; \mathrm{AU}=$ gold; $\mathrm{S}$ $=$ sulfur $; \mathrm{PD}=$ palladium $; \mathrm{K}=$ potassium $; \mathrm{CA}=$ calcium; $\mathrm{CL}=$ chlorine; $\mathrm{FE}=$ iron; $\mathrm{SR}=$ strontium; $\mathrm{BA}=$ barium; $\mathrm{MN}=$ manganese; $\mathrm{P}=$ phosphorous.
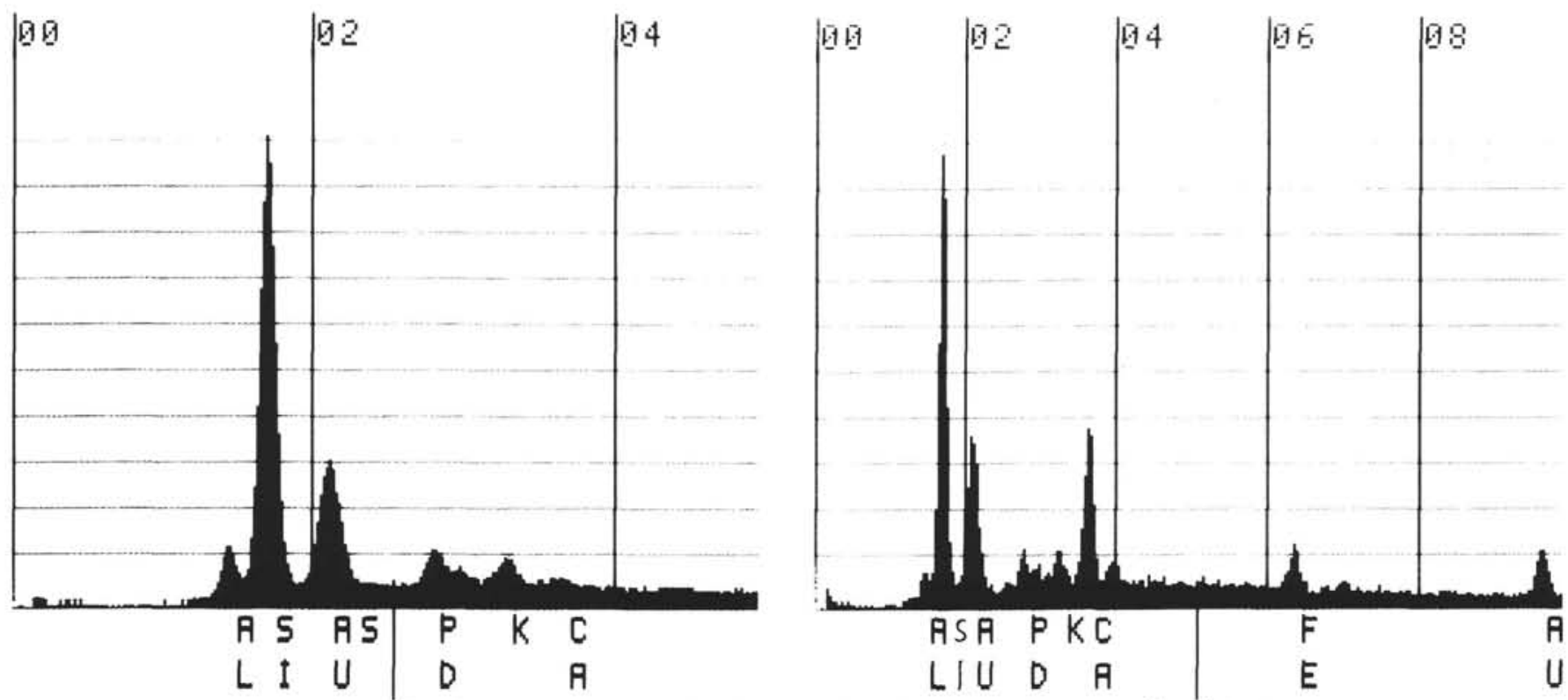

\section{CURSOR $(K E V)=02,560$}

EDAP

Appendix A-1. EDAX analysis of a characteristic clinoptilolite crystal with the typical EDAX spectrum for this mineral ( $\mathrm{Al}, \mathrm{Si}$, and $\mathrm{K})$.

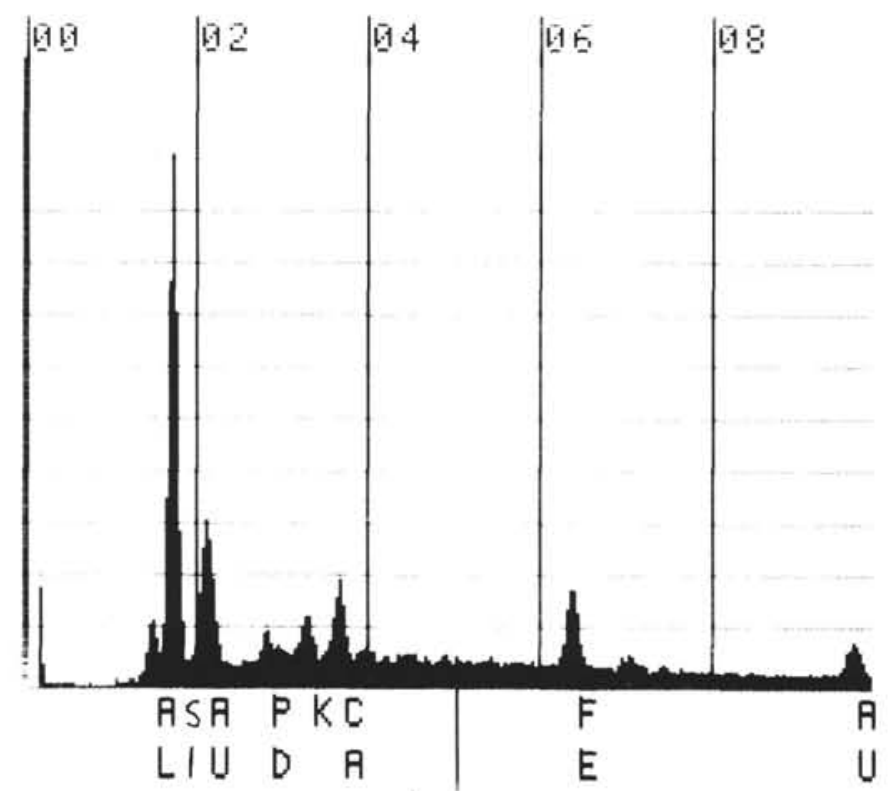

LUF SOF $\quad K E Y)=05.080$

E[HA:

Appendix A-2. EDAX analysis of the surrounding of "pseudolepispheres."
[UFSOR $(K E Y)=05.120$

EDAR and $\mathrm{Al}$ ).

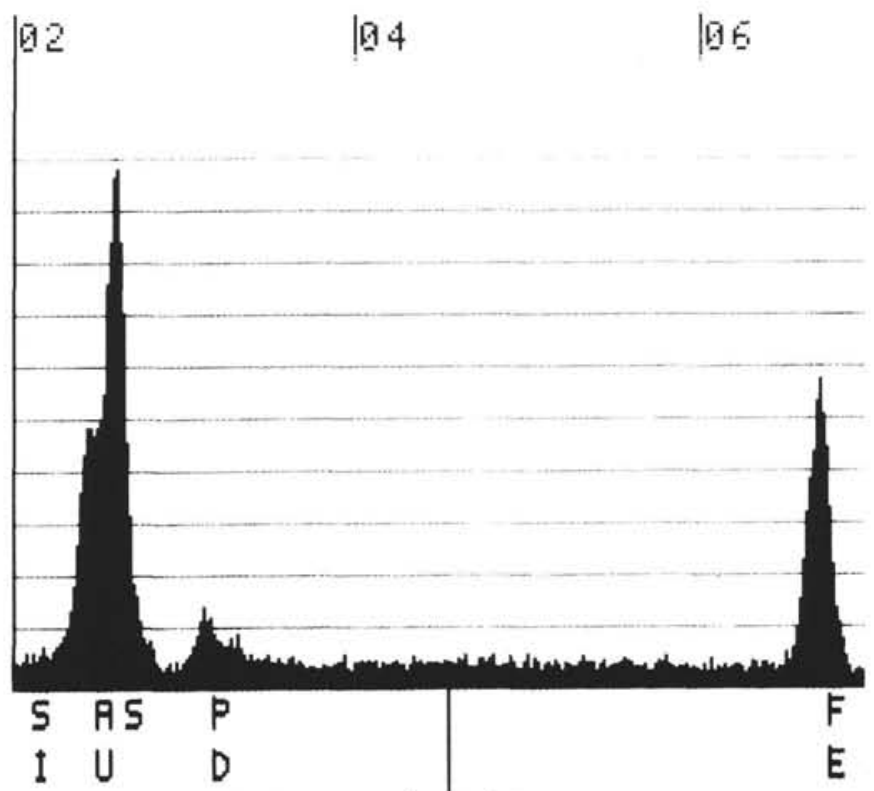

DURSOR $(K E V)=04.240 \quad E D A R$

Appendix A-4. EDAX analysis of the pyrite fill of a pyrite-replaced skeleton. 


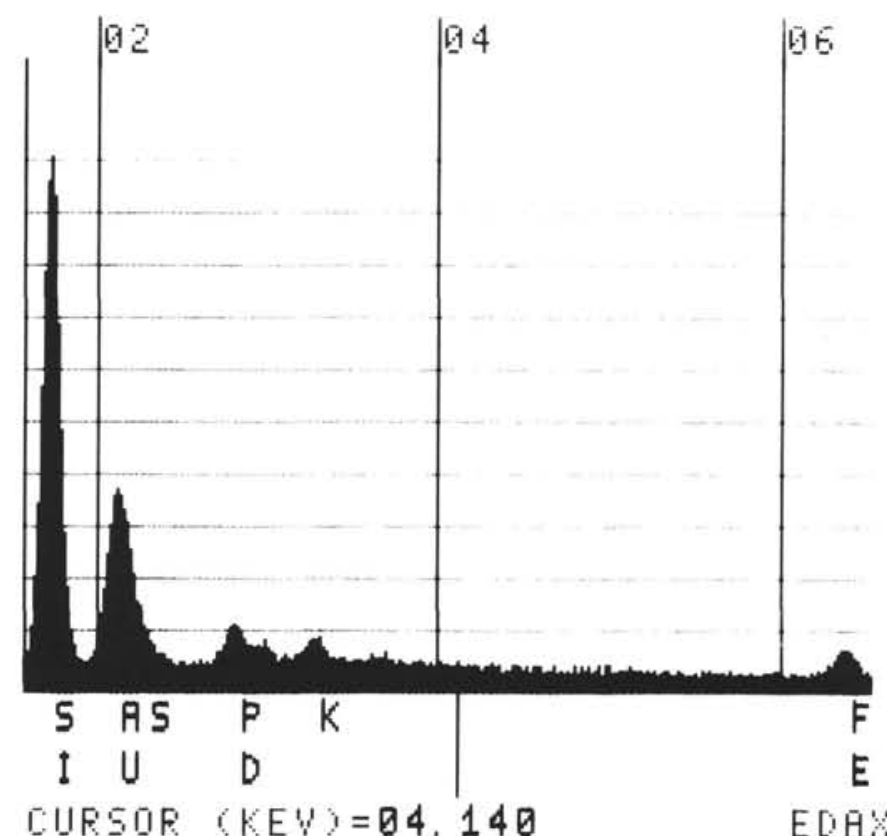

Appendix A-5. EDAX analysis of silica-replaced radiolarian skeleton (Si).

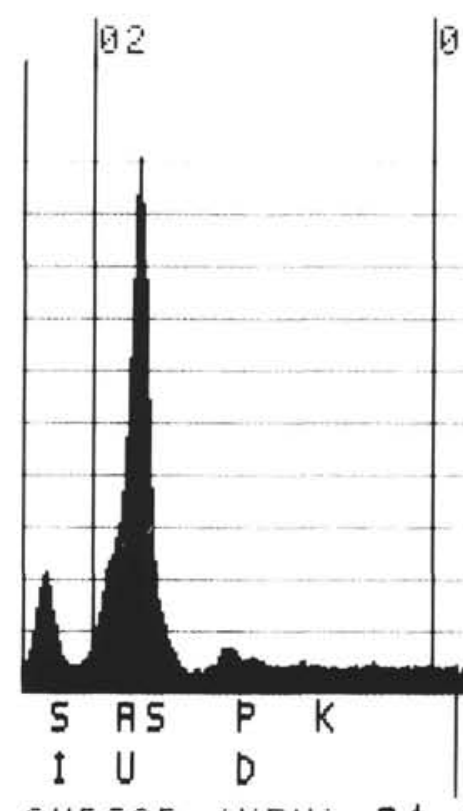

EUFSOF $(K E Y)=04.160$

Appendix A-6. EDAX analysis of pyrite crystals (S and Fe).

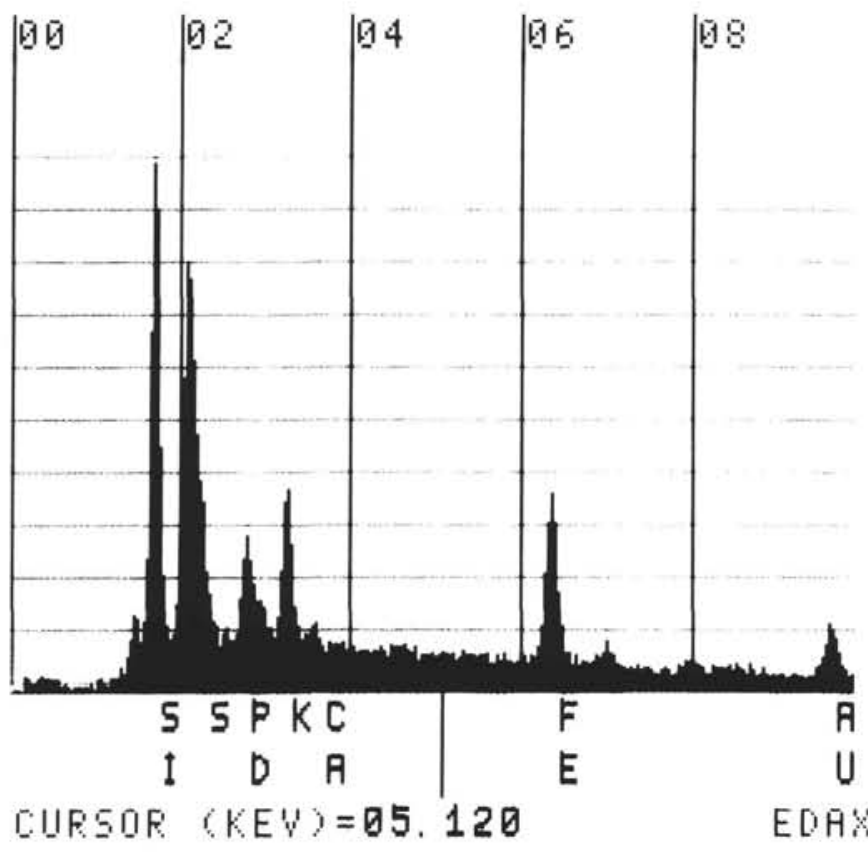

Appendix A-7. EDAX analysis of zeolite crystal (?clinoptilolite; $\mathrm{Si}$, $\mathrm{Al}$, and $\mathrm{K}$ ) in a pyrite-replaced skeleton. The pyrite surrounding the zeolite is apparently from the EDAX spectrum ( $\mathrm{S}$ and $\mathrm{Fe}$ ).

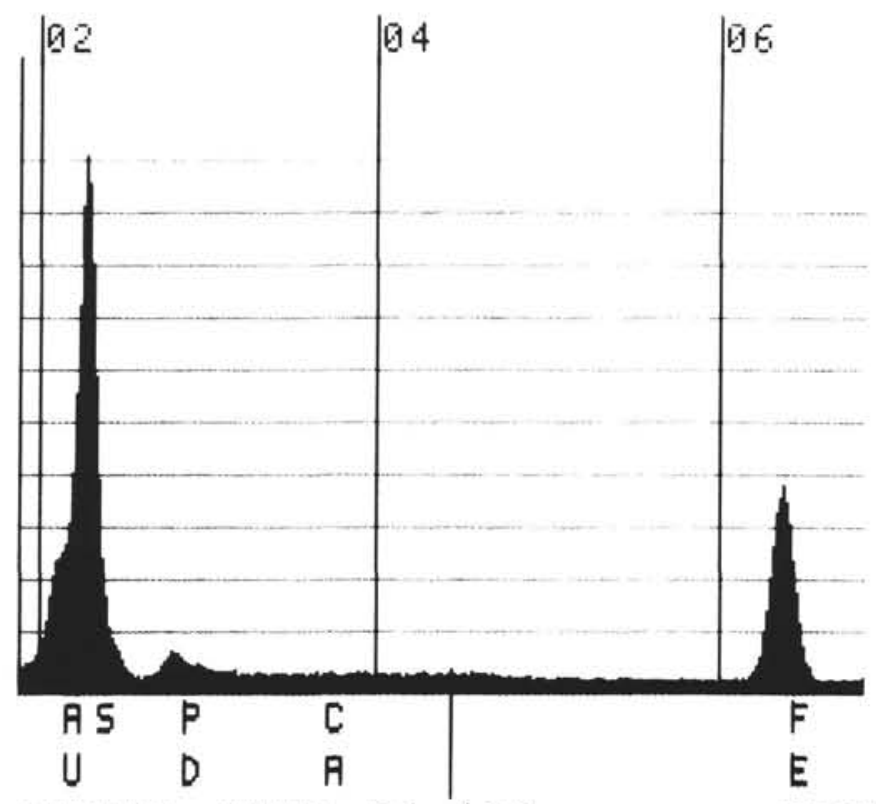

E D P $\mathrm{Y}$

Appendix A-8. EDAX analysis of a pyrite pseudomorph after zeolite. 


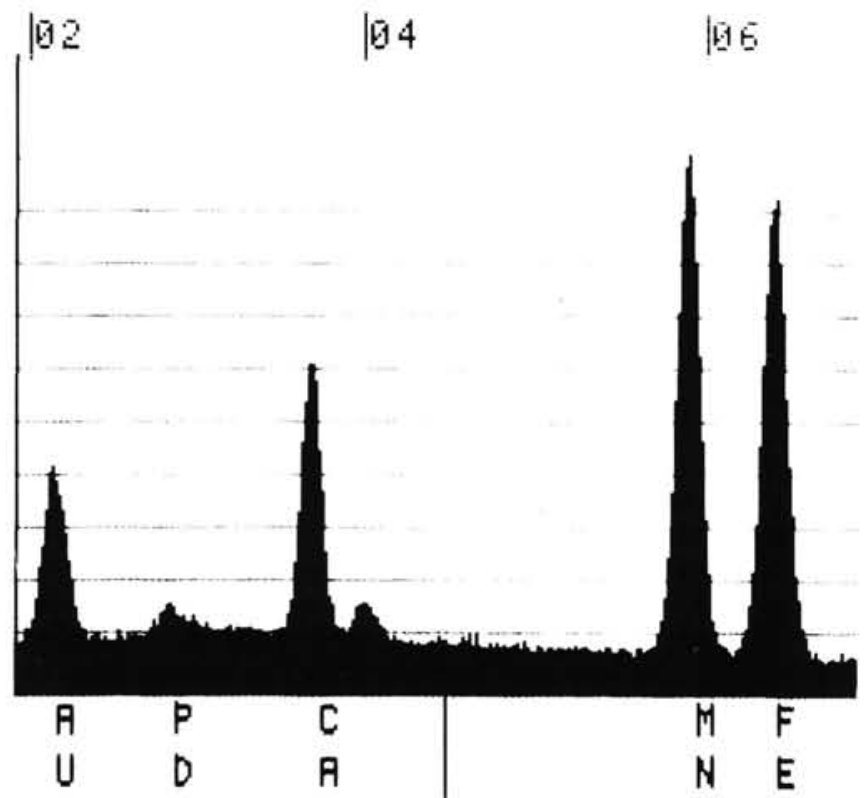

CURSOR $(K E V)=04.500$ ian skeleton. The habit of the crystals is that of clinoptilolite, but the EDAX spectrum of the crystal face in the center of the picture reveals large amounts of $\mathrm{S}$ and $\mathrm{Fe}$ (pyrite) that are not scattered from the surrounding area, as well as $\mathrm{Si}, \mathrm{Al}$, and $\mathrm{K}$.

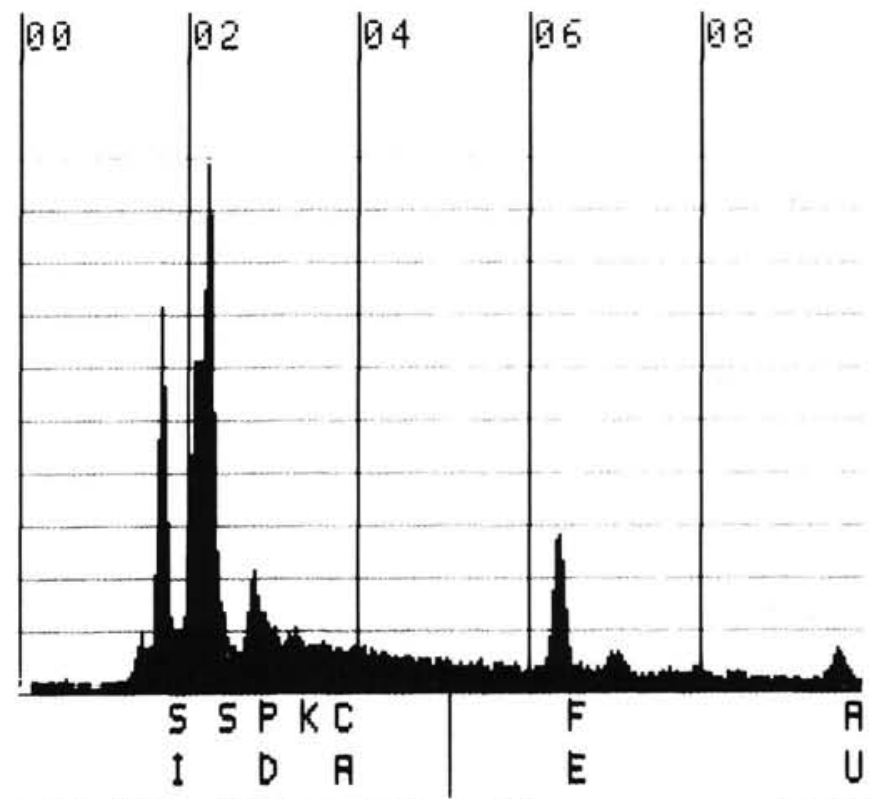

CURSOR $(K E V)=05.120$

EDAX

Appendix A-10. EDAX analysis of a sphere of unknown origin (Caand Fe-rich rhodochrosite).

\section{APPENDIX B}

Diagenetic Alteration of Radiolarians (Sites 398 and 603 and Leg 103)

A study of the noncalcareous fraction with the binocular microscope. No fragments were considered.

\section{Abundance}

Rare/few: present, but $<100$ specimens per $10 \mathrm{~cm}^{3}$

Common: $>100$ specimens per $10 \mathrm{~cm}^{3}$

Abundant: $>500$ specimens per $10 \mathrm{~cm}^{3}$

Preservation

$\mathrm{g}=$ good (specimens show little or no surface dissolution and/or overgrowth)

$\mathrm{m}-\mathrm{g}=$ moderate-good; $\mathrm{g}-\mathrm{m}=$ good-moderate (specimens show some dissolution and/or overgrowth, but not all species can be identified)

$\mathrm{m}-\mathrm{p}=$ moderate-poor $; \mathrm{p}-\mathrm{m}=$ poor-moderate $($ specimens show an intermediate degree of surface dissolution and/or overgrowth; identification of species is impaired, but some is possible)

$\mathrm{p}=$ poor (specimens show high degree of dissolution and/or overgrowth; identification of species level is rare)

\section{Diagenesis}

Samples containing remarkable amounts of skeletal fragments of siliceous sponges are marked with \#. Sponge remains have the same replacement mineralogy as the accompanying radiolarians (e.g., pyrite radiolarians and pyrite sponge fragments).

Surface dissolution indicates that the outer surface of the skeleton is smooth and species attributes are not visible.

Limonite-replaced skeletons and limonite lusters are probably the result of treatment with $\mathrm{H}_{2} \mathrm{O}_{2}$ and indicate primary pyrite.

The different types of alteration are described in the text "Diagenetic Replacement Processes." The following replacement/alteration processes are listed in this Appendix:

1. Replacement of opal-A by opal-CT, with rare recrystallization to quartz (type A)
2. Surface dissolution (corrosion) of skeletons (type B)

3. Replacement of skeletons by zeolites, especially by clinoptilolite (type C)

4. Replacement of zeolites by pyrite (type D)

5. Replacement of opal-A by pyrite (type E)

6. Formation of pyrite internal casts and dissolution of primary skeletons (type $\mathrm{F}$ )

7. Replacement of skeletons by calcite (type G)

Diagenetic types of less importance are

8. Pyrite/limonite lusters on skeletons (type $\mathrm{H}$ )

9. Zeolite internal casts (not always easily detectable) (type J)

10. Monospecific replacement by a certain mineral (e.g., opal-CT, whereas all other forms are replaced by pyrite) (type K)

Alteration processes displayed in parentheses are not unambiguously proven.

Sample interval

(core, section,

$\mathrm{cm}$ )

Type

Description

Radiolarian Samples from Hole 398D

$\begin{array}{ll}56-1,112-116 & \text { A (+ J) } \\ 56-2,2-6 & \text { A ( J) } \\ 56-2,10-12 & \text { A + J) } \\ 56-2,23-27 & \text { A ( J) } \\ 56-2,32-36 & \text { A ( J) } \\ 56-2,56-58 & \text { A ( J) } \\ 56-2,73-77 & \text { A (+ J) } \\ 56-2,82-86 & \text { A ( J) } \\ 56-2,98-102 & \text { A ( J) }\end{array}$

$\mathrm{c} / \mathrm{m}-\mathrm{p}$

$a / m-p$

$\mathrm{a} / \mathrm{m}-\mathrm{g}$

$a / m-p$

$f / p$

$\mathrm{a} / \mathrm{m}-\mathrm{p}$

$\mathrm{c} / \mathrm{m}-\mathrm{p}$

$\mathrm{c} / \mathrm{m}-\mathrm{p}$

$56-2,98-102$
.

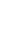




\begin{tabular}{|c|c|}
\hline $56-2,120-122$ & $A(+J)$ \\
\hline $56-2,139-143$ & $\mathrm{~A}(+\mathrm{J})$ \\
\hline $56-3,16-18$ & $\mathrm{~A}(+\mathrm{J})$ \\
\hline $56-3,43-47$ & $A(+J)$ \\
\hline $56-3,57-61$ & $A(+J)$ \\
\hline $56-3,145-149$ & $\mathrm{~A}(+\mathrm{J})$ \\
\hline $62-1,57-61$ & $\mathrm{~A}+\mathrm{H}(+\mathrm{J})$ \\
\hline $62-6,56-60$ & $\mathrm{~A}+\mathrm{H}(+\mathrm{J})$ \\
\hline$" 63-4,20-24$ & $\mathrm{~A}+\mathrm{H}(+\mathrm{J})$ \\
\hline $63-4,42-46$ & $A+B(+J)$, high diversity \\
\hline $63-4,135-139$ & $\mathrm{~A}+\mathrm{H}$, high diversity \\
\hline " $63-6,44-48$ & A \\
\hline$" 63-6,90-94$ & $\mathrm{~A}+\mathrm{H}$ \\
\hline $65-5,134-136$ & A $(+J)$, high diversity \\
\hline $67-1,69-73$ & $\mathrm{~A}+\mathrm{H}$ \\
\hline $68-3,140-144$ & $\mathrm{~A}+\mathrm{H}, \mathrm{B}$ \\
\hline $70-2,81-85$ & A \\
\hline $70-4,0-4$ & $\mathrm{~A}+\mathrm{H}$ \\
\hline $73-4,36-40$ & $\mathrm{~A}(+\mathrm{J})$ \\
\hline $72-3,42-46$ & $\stackrel{A}{A}+\mathrm{H}$ \\
\hline $\begin{array}{l}72-4,57-63 \\
72-4,99-103\end{array}$ & $\begin{array}{l}A+H \\
A(+J)\end{array}$ \\
\hline & $A(+J)$ \\
\hline $73-4,82-86$ & $\mathrm{~A}(+$ abundant $\mathrm{J}), \mathrm{H}$ \\
\hline $73-4,118-122$ & A \\
\hline $73-6,12-16$ & $A(+J), H$ \\
\hline$\# 74-3,52-56$ & A \\
\hline \#74-4, 23-27 & A \\
\hline $74-5,78-82$ & A $(+J)$, low diversity \\
\hline $75-2,37-41$ & A, high diversity \\
\hline $77-3,86-90$ & A, low diversity \\
\hline $77-4,43-47$ & A $(+J)$, low diversity \\
\hline $78-3,22-26$ & $\mathrm{~A}(+\mathrm{J})$, low diversity \\
\hline $78-5,0-4$ & $A(+J), H$ \\
\hline $79-1,0-4$ & $A+B$ \\
\hline $84-1,30-34$ & $\mathrm{~A}+\operatorname{rare} \mathrm{E}$ \\
\hline $89-4,66-70$ & A, high diversity \\
\hline $90-3,128-130$ & $A(+J), B$ \\
\hline $95-2,104-108$ & $\mathrm{~A}+\mathrm{B}$ \\
\hline $96-2,40-44$ & $A+E$ \\
\hline $97-4,45-50$ & $A(+J)$ \\
\hline $99-1,23-27$ & $A+B$ \\
\hline $99-6,120-124$ & $\mathrm{~A}+\mathrm{H}$ \\
\hline $100-2,0-2$ & $\mathrm{~A}+\mathrm{H}$ \\
\hline $100-3,148-150$ & $A+B$ \\
\hline $100-5,37-41$ & $A(+J)$ \\
\hline $101-5,98-102$ & $A(+J)$ \\
\hline $102-1,134-138$ & $A+B$ \\
\hline $102-6,18-21$ & A \\
\hline $103-1,128-132$ & A \\
\hline $106-2,44-48$ & $\mathrm{~A}+\mathrm{H}$, low diversity \\
\hline $114-4,117-119$ & A, low diversity \\
\hline $117-4,67-69$ & A, low diversity \\
\hline $117, \mathrm{CC}(0-2)$ & $\mathrm{A}+\mathrm{E}$, low diversity \\
\hline $118-4,74-76$ & A \\
\hline $137-3,36-38$ & A, low diversity \\
\hline
\end{tabular}

Radiolarian Samples from Hole 603B

$\mathrm{a} / \mathrm{m}-\mathrm{p}$
$\mathrm{c} / \mathrm{p}$
$\mathrm{c} / \mathrm{m}-\mathrm{p}$
$\mathrm{a} / \mathrm{m}-\mathrm{p}$
$\mathrm{a} / \mathrm{m}$
$\mathrm{c} / \mathrm{p}$
$\mathrm{a} / \mathrm{g}-\mathrm{m}$
$\mathrm{a} / \mathrm{g}-\mathrm{m}$
$\mathrm{a} / \mathrm{g}-\mathrm{m}$
$\mathrm{a} / \mathrm{p}-\mathrm{m}$
$\mathrm{a} / \mathrm{g}-\mathrm{m}$
$\mathrm{a} / \mathrm{g}-\mathrm{m}$
$\mathrm{a} / \mathrm{m}-\mathrm{g}$
$\mathrm{a} / \mathrm{m}-\mathrm{p}$
$\mathrm{c} / \mathrm{m}$
$\mathrm{a} / \mathrm{m}-\mathrm{p}$
$\mathrm{f} / \mathrm{m}$
$\mathrm{c} / \mathrm{p}$
$\mathrm{a} / \mathrm{m}-\mathrm{p}$
$\mathrm{a} / \mathrm{m}-\mathrm{p}$
$\mathrm{a} / \mathrm{m}-\mathrm{p}$
$\mathrm{c} / \mathrm{m}-\mathrm{p}$
$\mathrm{m}-\mathrm{p}$
$\mathrm{a} / \mathrm{m}$
$\mathrm{a} / \mathrm{m}-\mathrm{p}$
$\mathrm{a} / \mathrm{p}-\mathrm{m}$
$\mathrm{c} / \mathrm{m}-\mathrm{p}$
$\mathrm{c} / \mathrm{m}-\mathrm{p}$
$\mathrm{f} / \mathrm{m}$
$\mathrm{c} / \mathrm{m}$
$\mathrm{c} / \mathrm{m}-\mathrm{p}$
$\mathrm{c} / \mathrm{m}-\mathrm{p}$
$\mathrm{c} / \mathrm{m}-\mathrm{p}$
$\mathrm{f}-\mathrm{m}$
$\mathrm{f} / \mathrm{m}-\mathrm{p}$
$\mathrm{a} / \mathrm{p}-\mathrm{m}$
$\mathrm{a} / \mathrm{p}$
$\mathrm{a} / \mathrm{p}-\mathrm{m}$
$\mathrm{c} / \mathrm{p}$
$\mathrm{c} / \mathrm{p}$
$\mathrm{f} / \mathrm{p}$
$\mathrm{c} / \mathrm{p}-\mathrm{m}$
$\mathrm{c} / \mathrm{p}$
$\mathrm{f} / \mathrm{p}$
$\mathrm{f} / \mathrm{p}$
$\mathrm{f} / \mathrm{p}$
$\mathrm{f} / \mathrm{p}$
$\mathrm{a} / \mathrm{p}-\mathrm{p}$
$\mathrm{f} / \mathrm{m}-\mathrm{p}$

25, CC

26-1, 90-93

26-2, 90-93

26-3, 90-93

$26, \mathrm{CC}$

$33-1,48-52$

$33-1,90-93$

$33-2,90-93$

33-3, 48-52

$33, \mathrm{CC}$

$34-3,90$

$35-1,90-93$

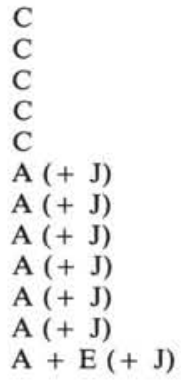

\section{Radiolarian Samples from Hole 638B}

Most of the radiolarians from the $\mathrm{CaCO}_{3}$-rich layers are replaced by calcite (type G). These faunas were dissolved by $\mathrm{HCl}$ etching of the samples.

21-1

21-1, 4-6

21-1, 61-65

21-1, 93-96

21-1, 128-132

21-2, 15-18

21-3, 72-74

$21-3,110-114$

$21-4,0-4$

21-4, 73-75

"21-4, 84-88

21-5, 52-54

$21-5,98-100$

21-5, 140-144

21-6, 21-25

"21-7, 15-18

21, CC

22-1, 14-18

22-2, 26-30

"22-3, 34-38

\#22-3, 105-109

$22-5,138-140$

23-1, 146-147

23-2, 0-4

24-3, 83-87

24-4, 126-130

24-6, 10-14

25-2, 43-47

$25-2,86-90$

25-5, 9-13

$25-6,19-23$

\section{5-6, 97-101}

25, CC

26-1, 21-25

26-2, 43-47

26-3, 89-93

26-6, 4-8

27-7, 54-58

28-3, 99-103

$30-2,115-119$

31-2, 34-38
21-4, 38-40

$27-1,107-111$
A, common fragmentation, tiny skeletons

A

A, imprints of calcite crystals

A (+ J), high diversity, imprints of calcite crystals

A $(+J)$, imprints of calcite crystals

$\mathrm{A}, \mathrm{H}(+\mathrm{J})$

$\mathrm{A}>\mathrm{H}(+\mathrm{J})$

$\mathrm{A}(+\mathrm{J})$

$\mathrm{A}(+\mathrm{J}), \mathrm{B}$

A, common fragmentation

A, E aggregates and $\mathrm{H}$

A, high diversity

A

$\mathrm{A}(+\mathrm{J})$

$\mathrm{A}(+\mathrm{J})$

$\mathrm{A}(+\mathrm{J})$

$\mathrm{A}(+\mathrm{J})$

A

$\mathrm{A}+$ (rare E)

$\mathrm{A}, \mathrm{B}$, and $\mathrm{E}$

$\mathrm{A}(+\mathrm{J}), \mathrm{H}$

A, rare $\mathrm{H}$

A

E + pyrite overgrowth

$\mathrm{E}+$ pyrite overgrowth

E

E

E, very tiny forms, sorted?

E

E

E, sample consists of $>50 \%$

calcite-replaced radiolarians and/or calcite internal casts

$\mathrm{E}$, flattened specimens

$\mathrm{E}+$ calcite internal casts

$\mathrm{E}+\mathrm{F}$, even fragile forms preserved

$\mathrm{H}$, mainly fragments

E

E, very tiny forms, sorted?

E

E, flattened specimens

$E+$ pyrite overgrowth

E + pyrite overgrowth

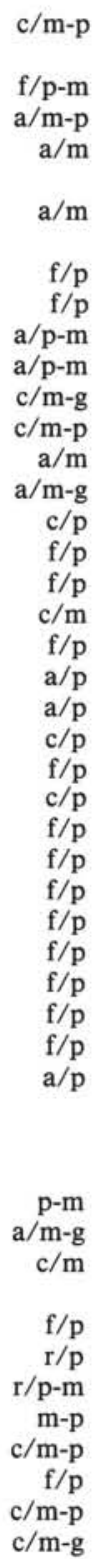

Downhole, only radiolarian morphotypes are detectable. No genera and species were identifiable.

32, CC (11-15)
$35-3,56-60$
$37-1,96-100$
$42-1,23-25$
$43-2,49-53$
$44-3,42-46$
44, CC
$45-1,50-53$
$45-1,67-69$

E, F, and pyrite overgrowth

$\mathrm{E}$, high diversity $-\mathrm{F}$ and $\mathrm{py}-$ rite overgrowth

$\mathrm{E}, \mathrm{F}$, and pyrite overgrowth

$\mathrm{E}$, high diversity $-\mathrm{F}$ and pyrite overgrowth

$\mathrm{E}$, high diversity $-\mathrm{F}$ and pyrite overgrowth

$\mathrm{E}, \mathrm{F}$, and pyrite overgrowth

$\mathrm{E}, \mathrm{F}$, and pyrite overgrowth

E, F, and pyrite overgrowth

$\mathrm{E}, \mathrm{F}$, and pyrite overgrowth $\mathrm{r} / \mathrm{p}$

f/p

$\mathrm{f} / \mathrm{p}$

f/p

$\mathrm{r} / \mathrm{p}$

$\mathrm{a} / \mathrm{p}$

r/p

$\mathrm{a} / \mathrm{p}$

$\mathrm{c} / \mathrm{p}$ 


\section{Samples from Hole $638 \mathrm{C}$ with Radiolarians}

Samples from Hole $638 \mathrm{C}$ contain only faunas with pyrite replacement (type $\mathrm{H}$ ) and pyrite overgrowth. Only morphotypes are distinguishable.

$\begin{array}{lll}3 R-3,0-4 & \text { E with strong pyrite over- } & \mathrm{r} / \mathrm{p} \\ \text { 4R, CC } & \text { E } \begin{array}{l}\text { growth } \\ \text { with strong pyrite over- } \\ \text { growth }\end{array} & \mathrm{r} / \mathrm{p} \\ 5 \mathrm{R}, \mathrm{CC} & \mathrm{E} \begin{array}{l}\text { with strong pyrite over- } \\ \text { growth }\end{array} & \mathrm{r} / \mathrm{p} \\ 6 \mathrm{R}, \mathrm{CC} & \mathrm{E} \begin{array}{l}\text { with strong pyrite over- } \\ \text { growth }\end{array} & \mathrm{r} / \mathrm{p} \\ 7 \mathrm{R}-1,148-150 & \mathrm{E} & \mathrm{r} / \mathrm{p} \\ 7 \mathrm{R}-2,0-2 & \mathrm{E} & \mathrm{r} / \mathrm{p}\end{array}$

Samples from Holes 639A, 640A, and 641A with Radiolarians (No Identification of Species)

Hole 639A:

$5 \mathrm{R}-1,106-108$

limonite replacement

$8 \mathrm{R}, \mathrm{CC}$

limonite replacement

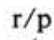

Hole 640A:

$\begin{array}{ll}3 R-3,138-142 & \mathrm{E} \\ 3 \mathrm{R}, \mathrm{CC} & \mathrm{H}, \text { fragmentation } \\ \text { 6R-1, 34-38 } & \mathrm{E} \\ \text { 6R, CC }(8-12) & \mathrm{E} \\ \text { 6R, CC }(21-24) & \mathrm{I} \\ \text { 6R, CC } & \mathrm{E}+\text { pyrite overgrowth } \\ \text { 6R-6, 122-126 } & \mathrm{C} \\ 7 \mathrm{R}-2,73-77 & \mathrm{~A}+\mathrm{H}\end{array}$

Samples from Hole $641 \mathrm{C}$ with Radiolarians

$1 \mathrm{R}-1,36-38$
${ }^{1 \mathrm{R}-2}, 56-59$
$1 \mathrm{R}-3,84-87$
${ }_{1 \mathrm{R}}-4,63-67$
${ }^{1 \mathrm{R}}-5,34-37$
${ }_{1 \mathrm{R}-6,36-39}$
$1 \mathrm{R}, \mathrm{CC}(1-3)$
${ }^{1 \mathrm{R}}, \mathrm{CC}$
$2 \mathrm{R}-1,28-32$

$2 \mathrm{R}-2,21-25$

"2R-3, 51-55

2R-4, 67-71

2R-5, 140-144

"2R-6, 9-13

\#2R, CC (15-19)

${ }^{*} 2 \mathrm{R}, \mathrm{CC}$
$\mathrm{A}+\operatorname{rare} \mathrm{E}$

$\mathrm{A}(+\mathrm{J}), \mathrm{C}$, and $\mathrm{I}$

$\mathrm{A}(+\mathrm{J}), \mathrm{H}$

$\mathrm{A}, \mathrm{B}$, and rare $\mathrm{E}$

A

$\mathrm{A}+\mathrm{I}$

$\mathrm{A}(+\mathrm{J})$, rare $\mathrm{E}+\mathrm{H}$

A

$\mathrm{A}+\mathrm{B}$, less fragile specimens dominate

A, less fragile specimens dominate

$\mathrm{A}(+\mathrm{J}, \mathrm{B})$, rare $\mathrm{E}+\mathrm{H}$

$\mathrm{A}(+\mathrm{J}), \mathrm{E}, \mathrm{H}$, nassellarians are dominant

A, low diversity, nassellarians dominant

A $(+\mathrm{J})$

A $(+\mathrm{J})$

A $(+\mathrm{J})$

$r / p$
$r / p$

$\mathrm{a} / \mathrm{m}-\mathrm{g}$

$\mathrm{a} / \mathrm{m}$

$\mathrm{r} / \mathrm{p}$

$\mathrm{r} / \mathrm{p}$

$r$

$\mathrm{r} / \mathrm{p}$

$\mathrm{r} / \mathrm{p}$

p

$/ \mathrm{p}$

p

p

p

(1)




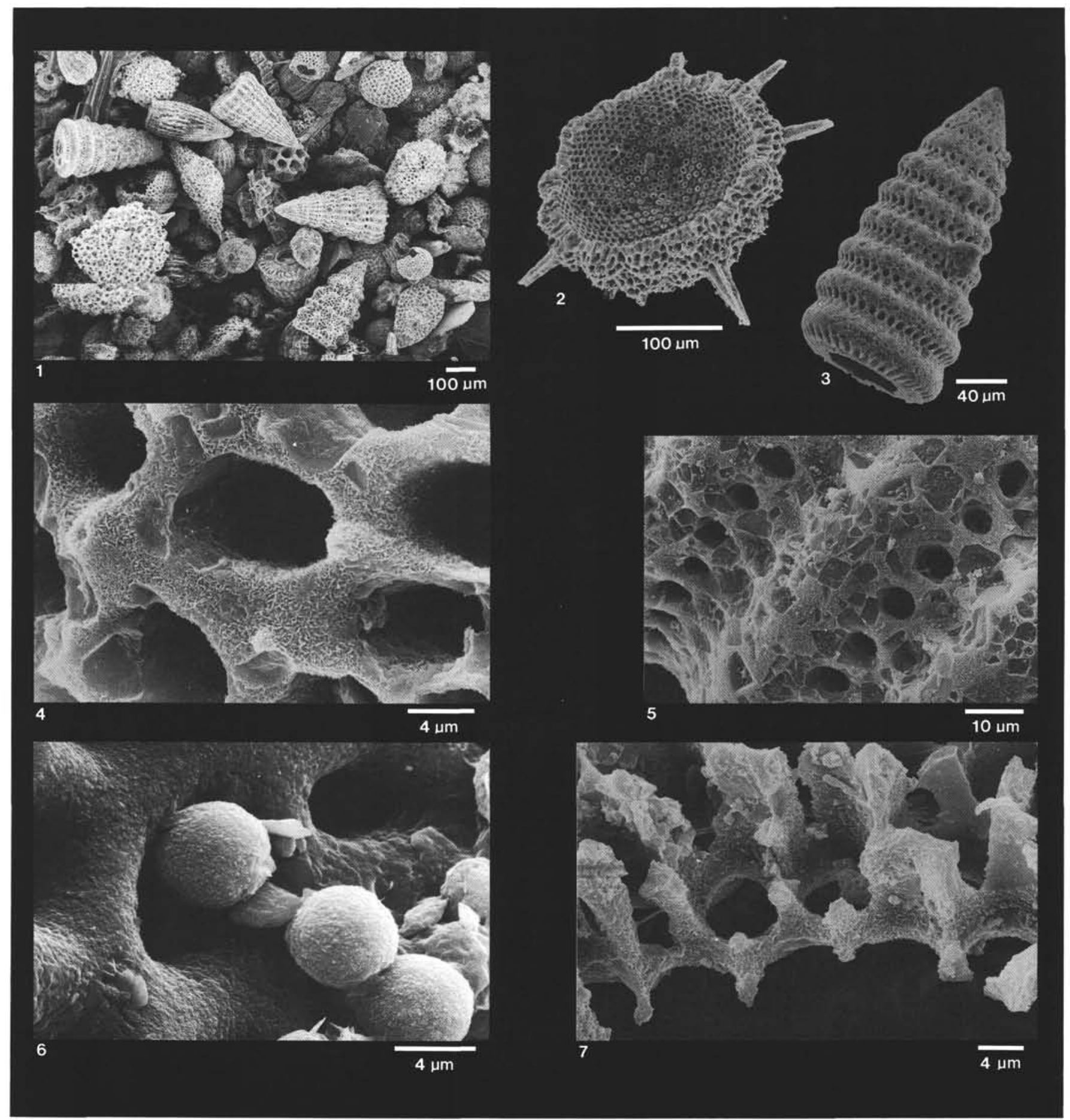

Plate 1. SEM photomicrographs. 1. Washed and etched residue of opal-CT-replaced radiolarians, abundant fragments of terrestrial plants, and light mica. Sample 103-638B-21R-1, 93-96 cm (Barremian). 2. Spumellarian replaced by opal-CT (compare with Fig. 4) showing well-preserved gross morphology. Sample 103-638B-21R-5, 52-54 cm. 3. Nassellarian (Pseudodictyomitra lilyae) replaced by opal-CT with abundant imprints of $\mathrm{CaCO}_{3}$ crystals (dissolved by $\mathrm{HCl}$ treatment). Sample 103-638B-21R-5, $52-54 \mathrm{~cm}$. 4. Inner surface with network of regularly intertwinned opal-CT blades and imprints of $\mathrm{CaCO}_{3}$ infill. Note the dense wall structure (thin sections of these areas show crystallization of silica-quartz?. Sample 103638B-21R-1, 93-96 cm. 5. Close-up of Figure 3, with various imprints of $\mathrm{CaCO}_{3}$ crystals from the surrounding sediment (compare with Pl. 8, Fig. 4). 6. Dense silica-replaced radiolarian test with spherical (quartz?-replaced) opal-CT lepispheres on the inner surface. Sample 398D-63-4, 20-24 $\mathrm{cm}$. 7. Opal-CT and microcrystalline quartz (visible in thin sections) coating skeletal plate lattice structure. Sample 103-638B-21R-5, 52-54 cm. 


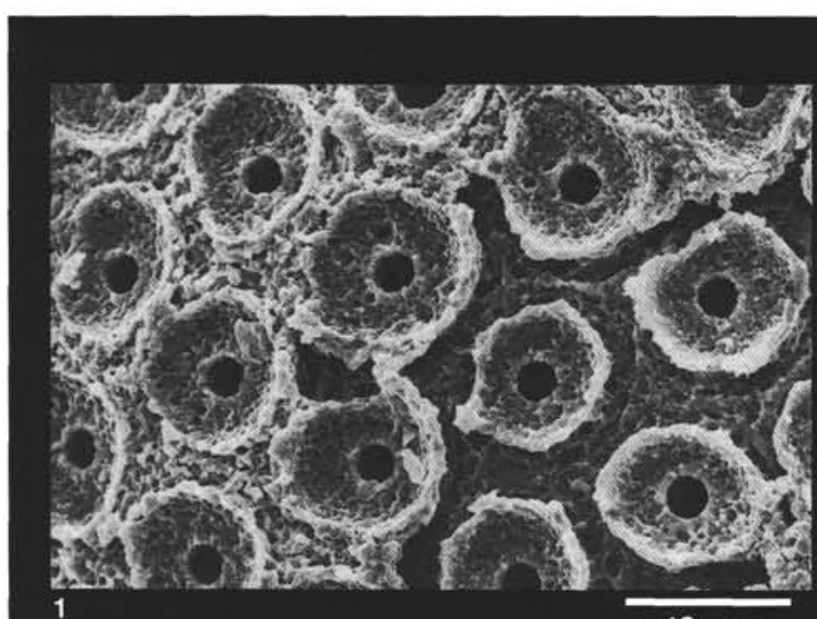

$10 \mu \mathrm{m}$

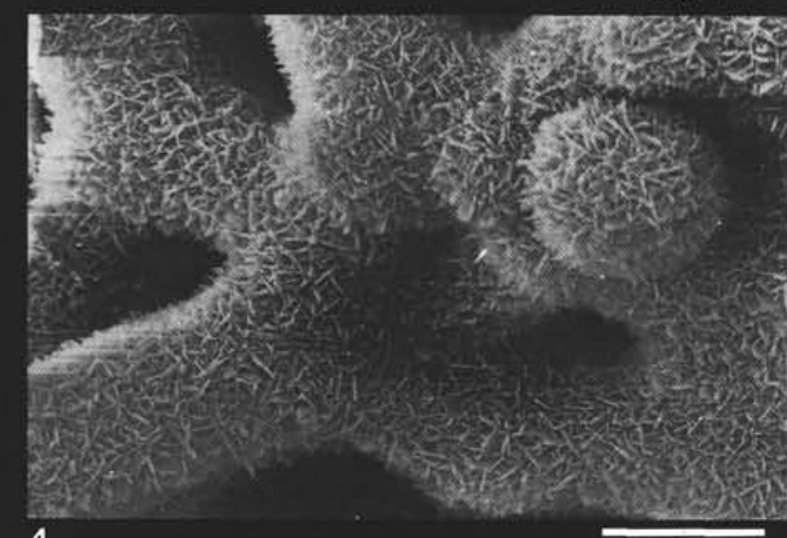

$4 \mu \mathrm{m}$

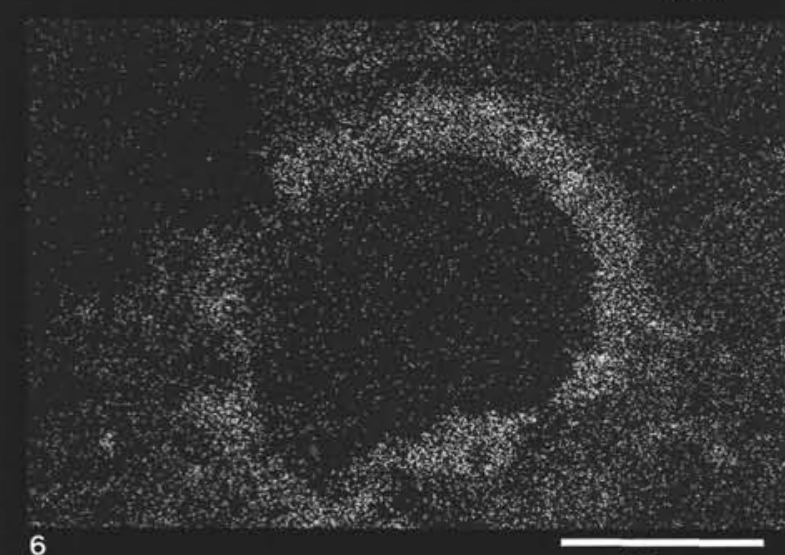

6

$40 \mu \mathrm{m}$

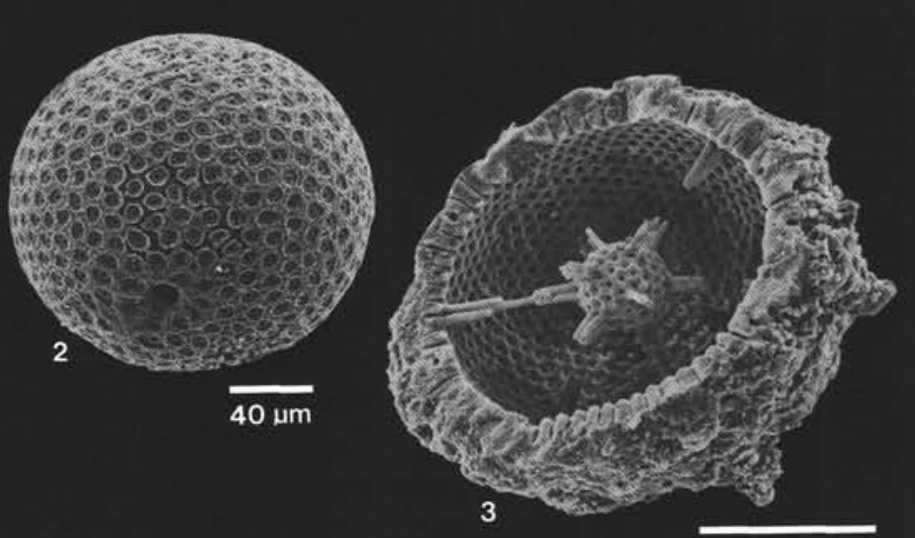

$100 \mu \mathrm{m}$

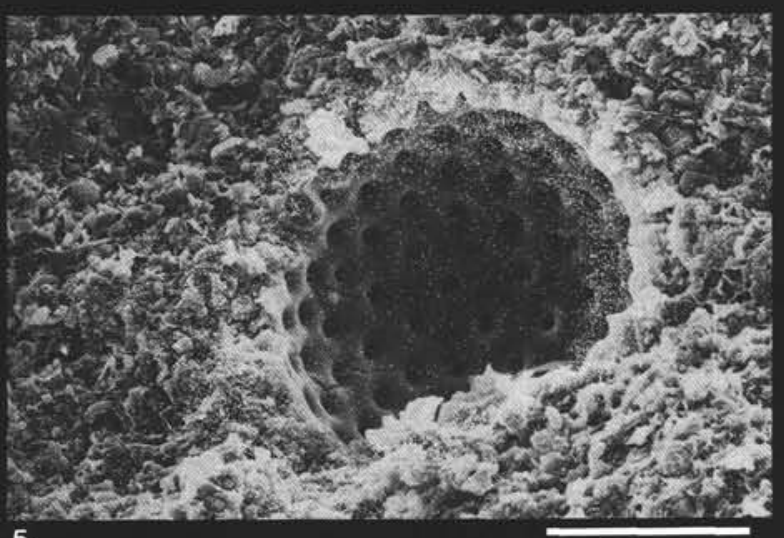

$40 \mu \mathrm{m}$

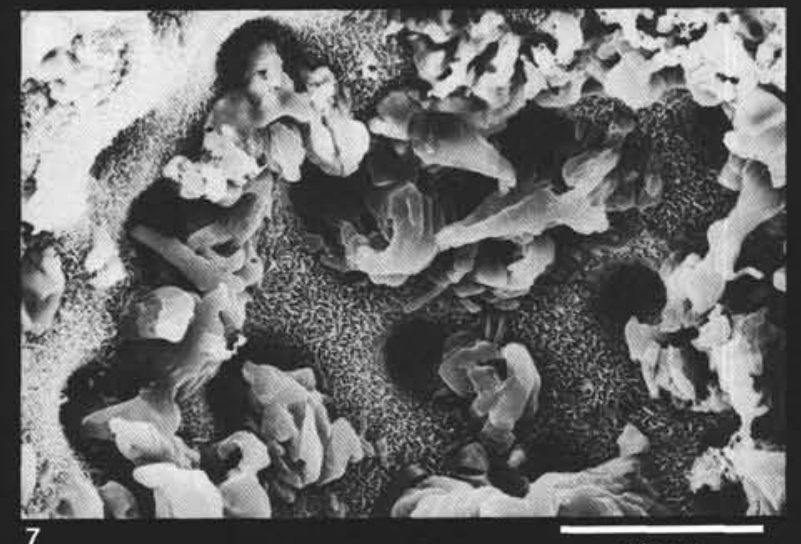

$10 \mu \mathrm{m}$

Plate 2. SEM photomicrographs. 1. Close-up of Figure 2, with solution pits and partly dissolved surface. 2. Quartz- or dense opal-CT-replaced skeleton with solution patterns on the surface. Section 103-640A-3R, CC. 3. Spumellarian replaced by opal-CT. The outer surface is highly modified and shows common dissolution and the formation of opal-CT lepispheres. The inner part and the medullary shell of the skeleton show fine preservation. The wall consists of massive silica. Sample 103-641C-4R-4, 47-49 cm. 4. Close-up of Figure 3, with opal-CT blades and opal-CT lepisphere. 5. Opal-CT-replaced spumellarian in nannofossil marlstone. Pattern of white dots is distribution of chlorine $(\mathrm{NaCl})$ from salt in interstitial waters that preferentially evaporated in the radiolarian test. Sample 103-638B-21 R-5, 98-100 cm. 6. Silica distribution in the area of Figure 5. Note abundant silica dots in the sediment around the radiolarian test. 7. Close-up of Figure 5 after $1 \mathrm{yr}$ of storage. Note salt crystals growing from the nannofossil marlstone into the radiolarian test and opal-CT blades on the inner surface of radiolarian test. 


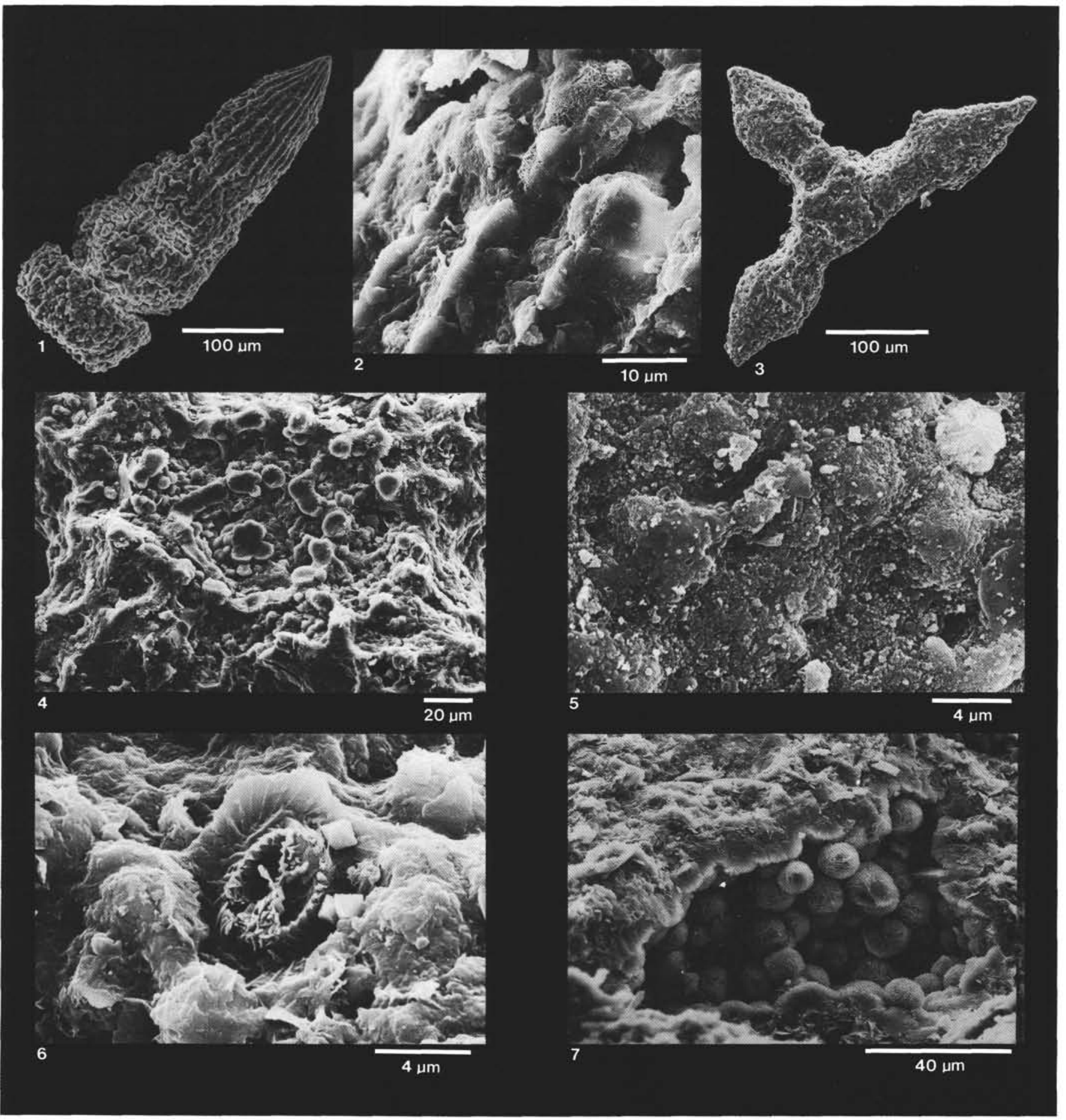

Plate 3. SEM photomicrographs. 1. Opal-CT replacement of nassellarian (Archaeodictyomitra sp.). The gross morphology of the test is well preserved to the upper right, whereas to the lower left, only the internal cast consisting of dense packed opal-CT lepispheres is preserved. Sample 398D63-4, 20-24 cm. 2. Close-up of Figure 1. The test still shows a dense outer surface, whereas opal-CT blades are visible inside. 3. Completely dissolved and now smooth surface of quartz-replaced skeleton. Section 103-638B-21R, CC. 4. Opal-CT-replaced nassellarian (Hexapyramis pantanellii). Note the internal structural elements of the skeleton replaced by dense silica (opal-CT or quartz) and the cast with quartz-replaced lepispheres with well-preserved gross morphology from the original opal-CT stage. Sample 398D-63-4, 20-24 cm. 5. Surface dissolution with the tendency to even the relief of the skeleton (note the flaky character in some areas-microcrystalline quartz?). Sample 103-641C-1R, CC (1-3 cm). 6. Coccolith replaced by silica and overgrown by pyrite octahedrons on the surface of an opal-CT-replaced radiolarian skeleton. Sample 103-641C-1R, CC (1-3 $\mathrm{cm})$. 7. Part of a radiolarian skeleton with heavy opal-CT replacement and recrystallization in zeolitic brown clay. Sample 398D-56-2, 2-6 cm. 


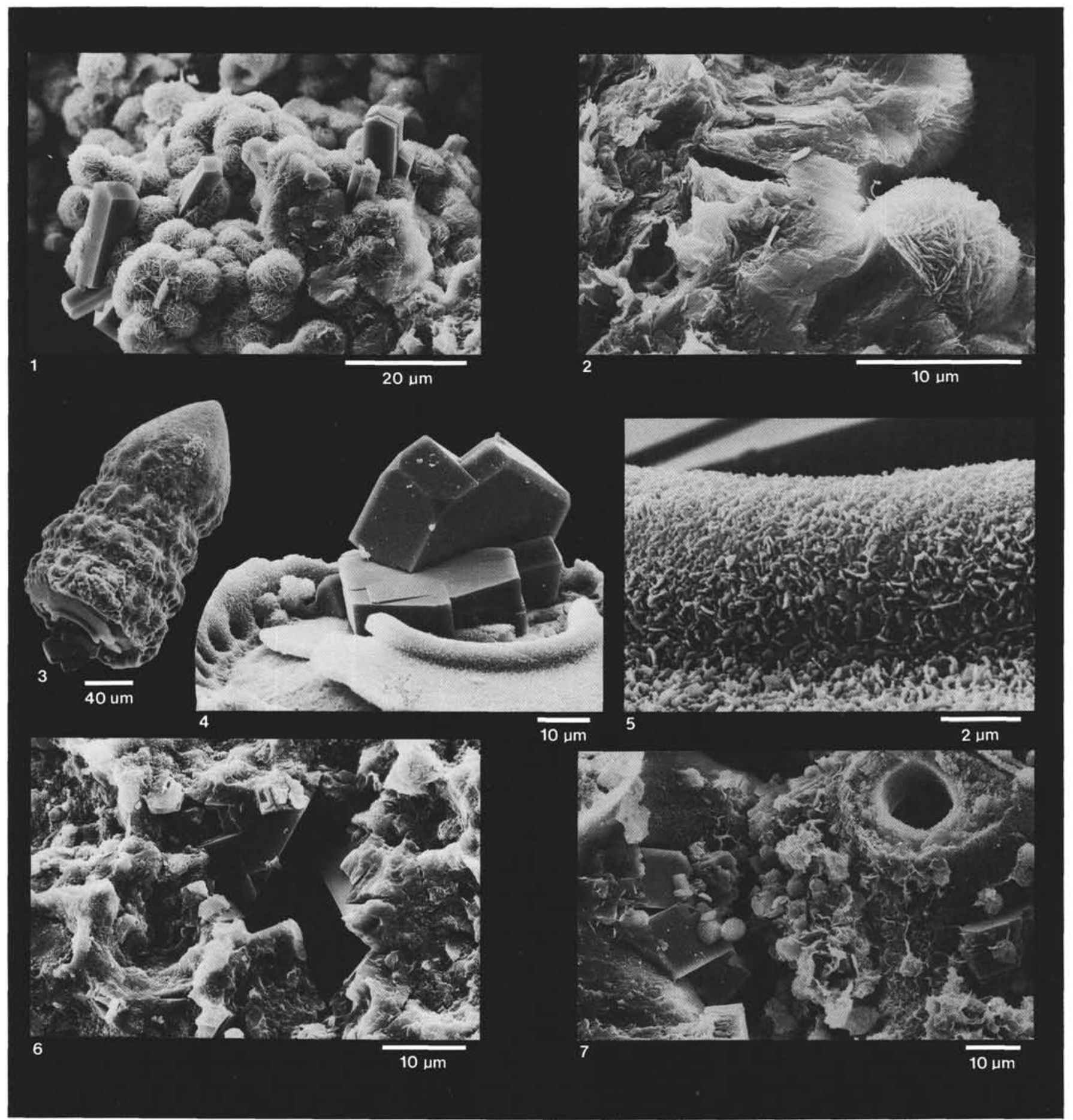

Plate 4. SEM photomicrographs. 1. Internal part of a radiolarian ghost in Upper Cretaceous smectite-rich zeolitic brown clay with abundant opalCT lepispheres and zeolite crystals. The skeleton was replaced by opal-CT lepispheres followed by later crystallization of zeolite (clinoptilolite), but opal-CT overgrowth is also visible in areas of the clinoptilolite crystals. Sample 398D-56-2, 2-6 cm. 2. Close-up of Plate 3, Figure 7, showing the dense opal-CT-replaced skeletal wall and opal-CT lepispheres coating the inner surface. 3. Opal-CT-replaced skeleton of Pseudodictyomitra pseudomacrocephala (fragment). Sample 603B-33-2, 90-93 cm. 4. Close-up of Figure 3. Broken test with clinoptilolite crystal growth in post-abdominal chambers. 5. Close-up of Figure 3. Detail of wall structure with opal-CT blades. 6. Radiolarian test replaced by clinoptilolite (compare with Fig. 3 in the text). The walls around pores are replaced by clinoptilolite in addition to clinoptilolite growth on the inner surface. Sample 603B-26-2, 90-93 $\mathrm{cm}$. 7. Growth of clinoptilolite and opal-CT lepispheres on silica-replaced skeleton. Sample 103-641C-3R, CC (12-16 cm). 

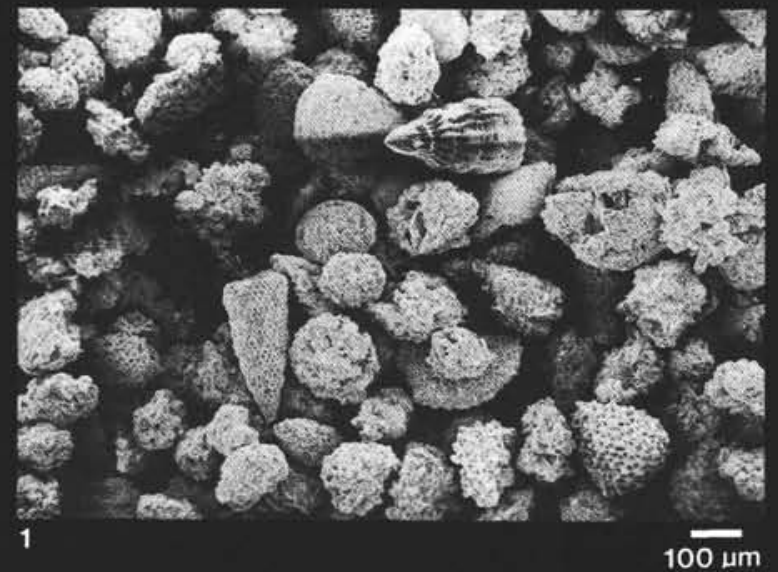
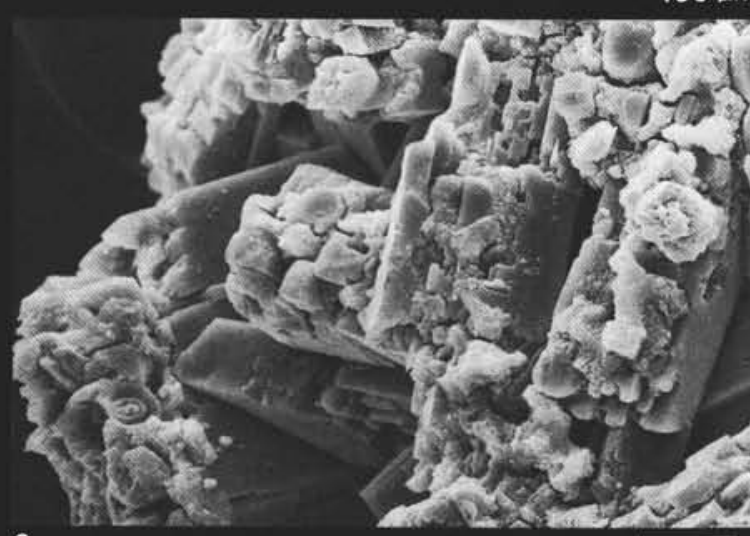

3

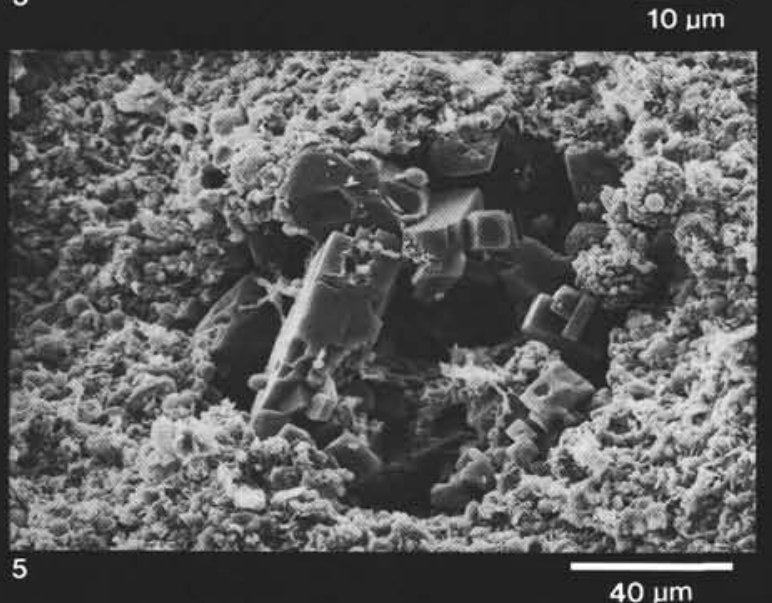

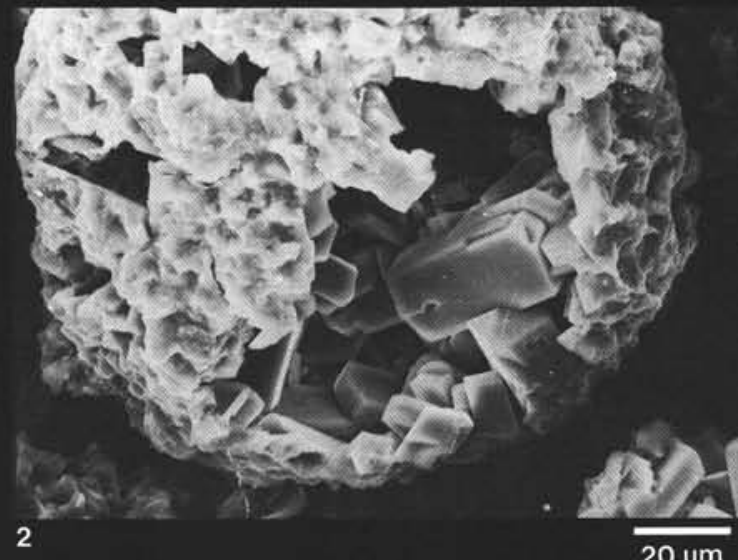
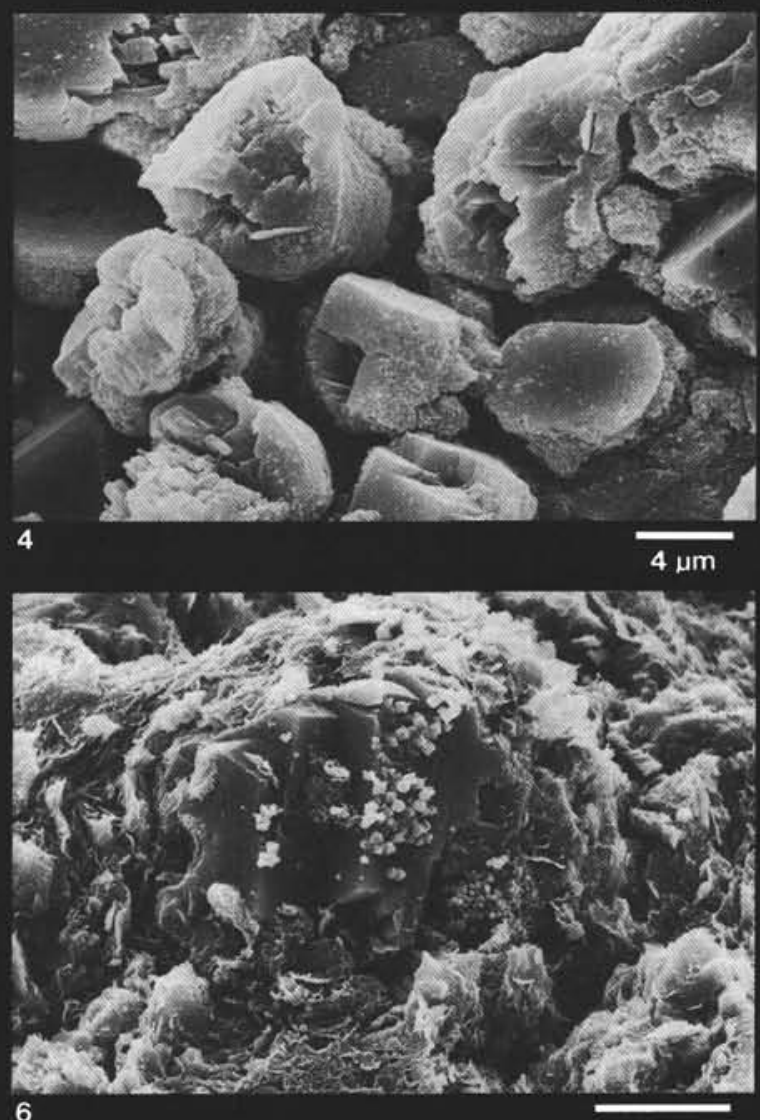

$10 \mu \mathrm{m}$

Plate 5. SEM photomicrographs. 1. Radiolarian fauna almost completely replaced by clinoptilolite. Sample $603 \mathrm{~B}-26-2,90-93 \mathrm{~cm}$. 2. Clinoptilolite replacement of a skeleton; the skeleton is also filled with coarse clinoptilolite crystals. Sample $603 \mathrm{~B}-26-2,90-93 \mathrm{~cm}$. 3. Relicts of opal-CT? on clinoptilolite internal cast. Section 103-638B-22R, CC. 4. Clinoptilolite internal cast with negative image of skeleton inner wall. Note remaining opal-CT blades between the rounded pore casts of clinoptilolite. Section 638B-22R, CC. 5. Nannoconus-rich marlstone with radiolarian ghost. At the upper right boundary of the original wall, coarse calcite crystals are visible. The cavity is filled with clinoptilolite, and framboidal pyrite formed center right. Sample 103-638B-21R-5, 98-100 cm. 6. "Clay ball" with clinoptilolite nucleus; the skeleton was dissolved. Note white pyrite octahedrons on surface of the clinoptilolite crystals. Sample 103-641C-3R, CC (12-16 cm). 


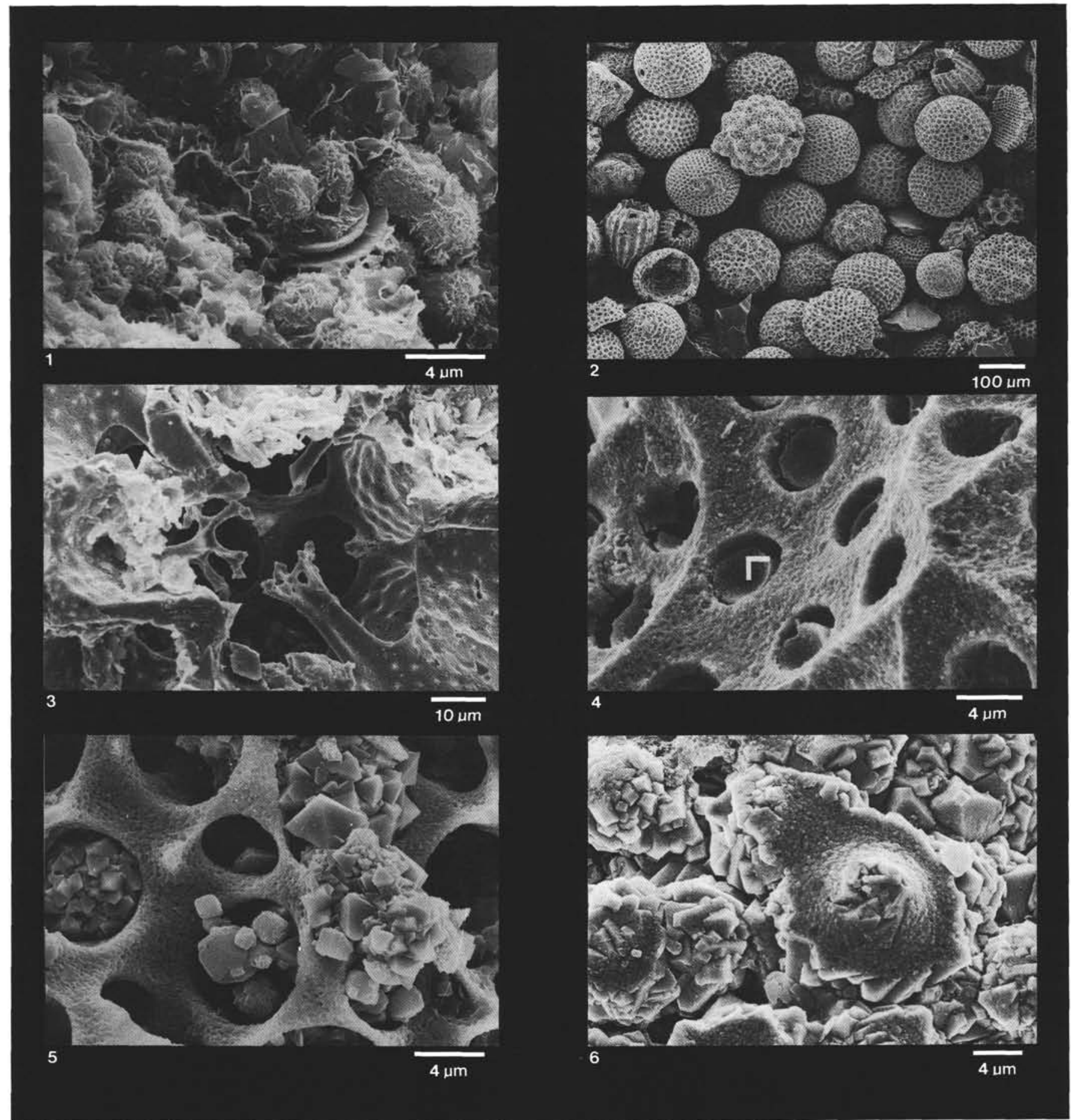

Plate 6. SEM photomicrographs. 1. Lepispheres grown in clayey nannofossil-rich environment. Note the flaky character of the lepispheres and the formation of opal-CT blades only as a surface coating of the lepispheres. Sample 103-641C-7R-1, 102-104 cm. 2. Radiolarian fauna of Barremian age. The skeletons are completely replaced by pyrite. Sample 103-640A-3R-3, 138-142 cm. 3. Internal skeletal attributes of Pantanellium lanceola replaced by pyrite. Note the fine preservation even of delicate structures. Section 103-640A-3R, CC. 4. Detail of pyrite-replaced skeleton (Williriedellum gilkeyi) with pyrite internal casts visible in the pores. Section 103-640A-3R, CC. 5. Detail of pyrite-replaced skeleton with solution pits and overgrowth of pyrite and chabazite(?). Note the framboidal pyrite in the center left. Advanced stage of dissolution and overgrowth of massive pyrite on the right. Sample 103-638B-31R-2, 34-38 cm. 6. Negative image of the inner surface of a skeleton on a heavily recrystallized, pyritic radiolarian internal cast. Section 103-638C-5R, CC. 


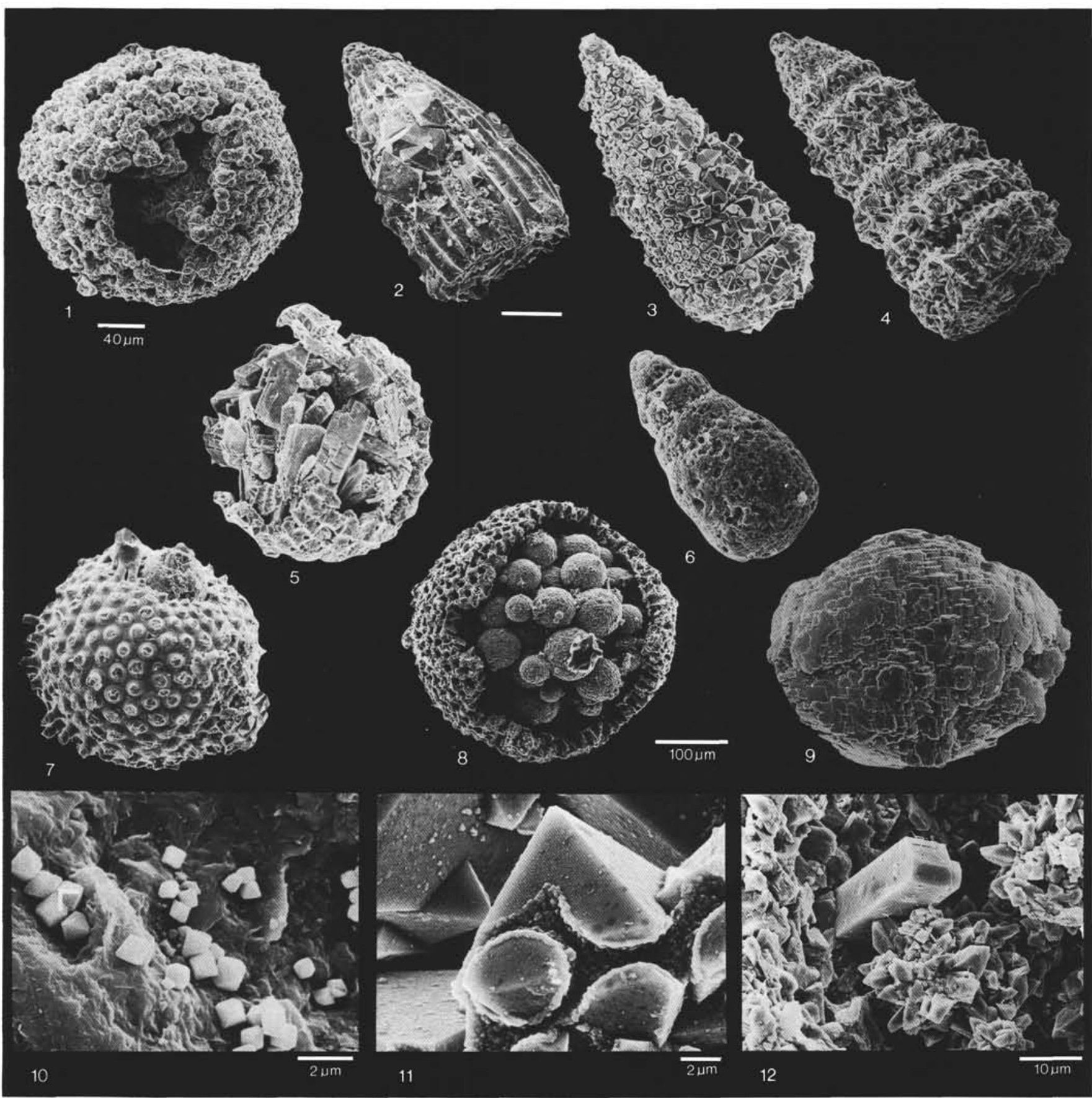

Plate 7. SEM photomicrographs. 1. Pyrite replacement of a radiolarian ghost. The area of the former skeleton is now occupied by framboidal pyrite. Section 103-638C-5R, CC. 2. Nassellarian (Archaeodictyomitra vulgaris) replaced by a massive overgrowth of coarse pyrite crystals. Section 103-638B-31R, CC. 3. Pyrite internal cast of a nassellarian. Section 103-638B-44R, CC. 4. Tabular euhedral pyrite crystals replacing or creating an internal casting of a (?)nassellarian skeleton. Section 103-638B-22R, CC. 5. Spumellarian skeleton replaced by massive pyrite and coarse-grained pyrite, which replaced clinoptilolite. Section 103-638B-22R, CC. 6. Radiolarian cast consisting of an aggregate of minute zeolite crystals and clay. Sample 103-641C-13R-2, 115-119 cm. 7. Pyrite internal cast of a cryptocephalic nassellarian. Note the perfect casting of cephalis, thorax, and abdomen, as well as pores (coarse casting of the sutural pore, upper center left). Pyrite overgrowth on the lower right. Section 103-638B-31R, CC. 8. Pyrite-replaced spumellarian filled with large framboidal pyrite. Sample 103-641C-9R, CC (11-14 cm). 9. "Pseudoradiolarian" proven by XRD to be a spherical dolomite concretion. These microconcretions can be easily mistaken for poorly preserved radiolarians. Such dolomites and/or Fe/Mn carbonates (Appendix A-10) are spherical, triangular, crossed (twinned) microconcretions. They are regularly dispersed in the red clays of the Plantagenet Formation. The carbonates may comprise up to $1 \%$ of the sediment. Similar microconcretions in coeval strata have been described from Site 603 (von Rad and Botz, 1987) and from onshore Morocco (Thurow, 1987). Sample 103-641A-5X-1, 5-9 cm. 10. Relict pores filled with silica and costae of opal-CT-replaced radiolarian test showing overgrowth with single pyrite crystals. Sample 103-641C-1R, CC (1-3 cm). 11. Close-up of Figure 3. Detail of internal cast. The pore-casting pyrite crystals are incorporated in larger overgrowth crystals. 12. Clinoptilolite crystal growing in the inner cavity of a pyrite-replaced skeleton. Section 103-638B-22R, CC. 

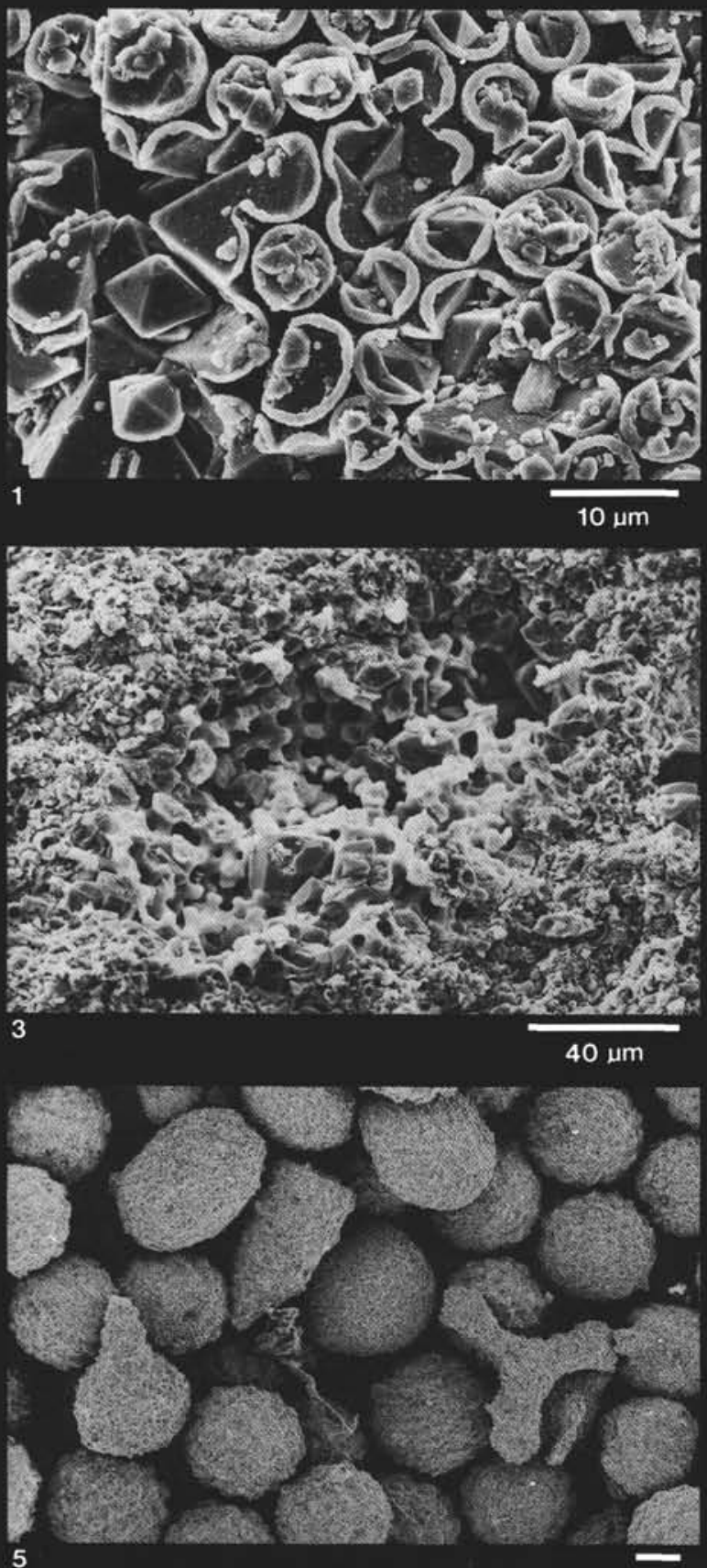
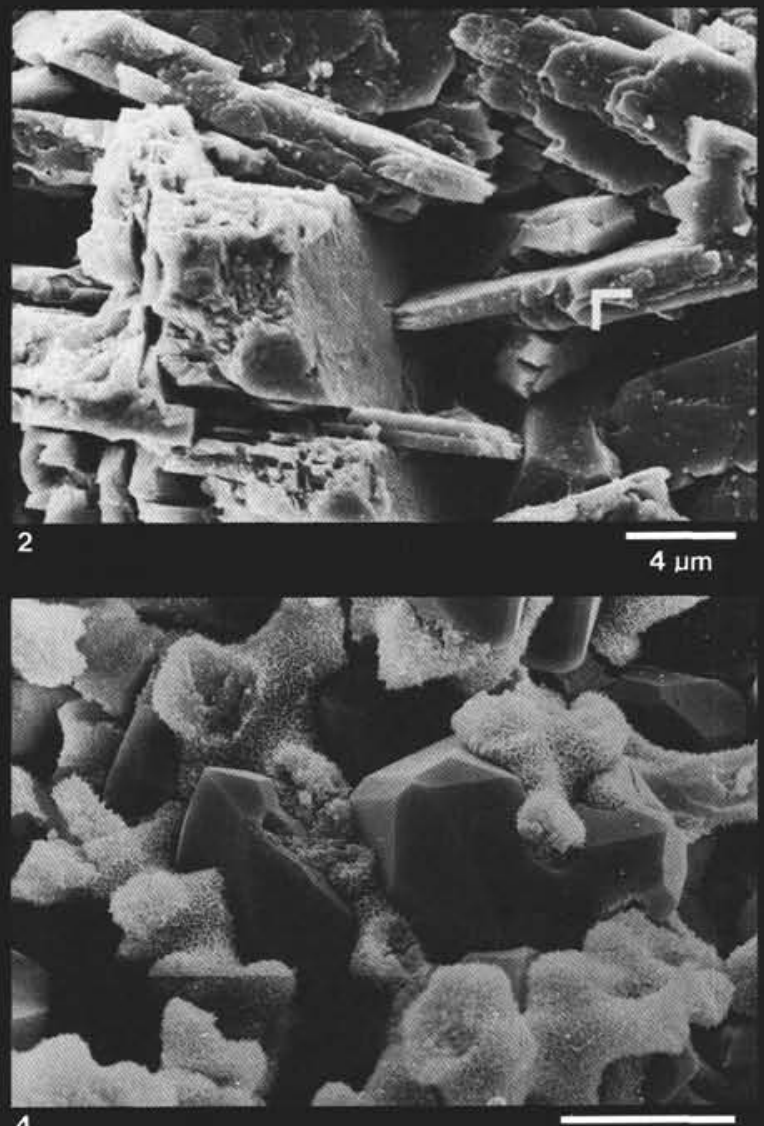

$10 \mu \mathrm{m}$

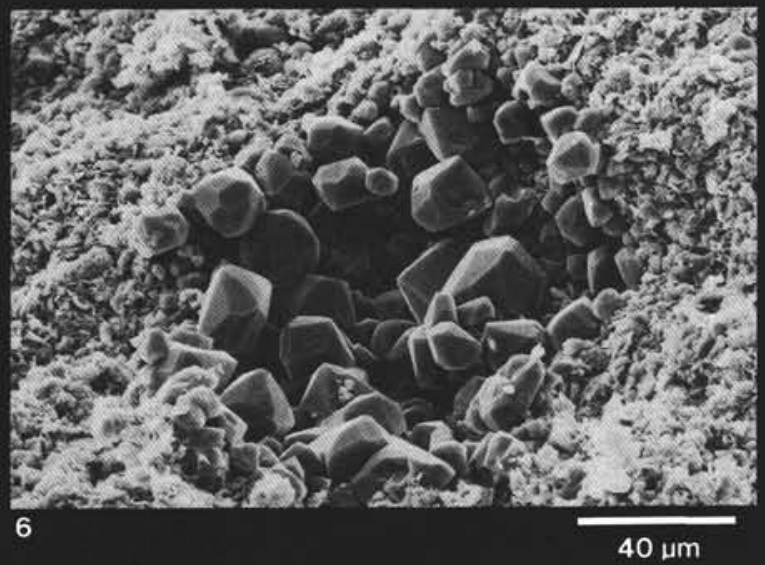

Plate 8. SEM photomicrographs. 1. Close-up of Plate 7, Figure 3. Negative images of internal skeletal morphology and larger overgrowth pyrite crystals. 2. Zeolitic crystal habit of pyrite internal cast (replacement of zeolite?). Section 103-638B-22R, CC. 3. Opal-CT-replaced skeleton in Nannoconus-rich marlstone. Sample 103-638B-21R-5, 98-100 cm. 4. Close-up of Figure 3 showing coarse calcite crystals growing from the surface into an opal-CT-replaced skeleton, thereby displacing and destroying it (see Pl. 1, Fig. 5). 5. Calcite-replaced radiolarian fauna from Barremian limestone (sediment treated with a detergent). The radiolarians are completely replaced by calcite but the gross morphology of the skeletons is preserved. Sample 103-638B-25R-6, 19-23 cm. 6. Complete dissolution of the skeleton and replacement with coarse calcite crystals. Note the increasing crystal size toward the center of the cavity. Sample 103-638B-21R-5, 98-100 cm. 